\title{
Bir Tekstil İşletmesinde Yalın Altı Sigma İle Süreç İyileştirmeye Yönelik Bir Örnek Olay Çalışması1 \\ (A Case Study for Process Improvement with Lean Six Sigma in A Textile Industry)
}

Gülseren ÇELEBİ GÜRSOY iD a Mehmet Selami YILDIZ iD

a Düzce Üniversitesi, Sosyal Bilimler Enstitüsü, Toplam Kalite Yönetimi Anabilim Dalı, Düzce, Türkiye. gulseren.celebi96@gmail.com

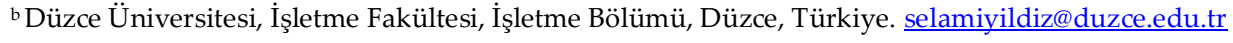

\begin{tabular}{|c|c|}
\hline MAKALE BİLGİSİ & ÖZET \\
\hline $\begin{array}{l}\text { Yalın Üretim } \\
\text { Yalın Altı Sigma } \\
\text { İş Süreci İyileştirme }\end{array}$ & $\begin{array}{l}\text { Amaç - Bu araştırmanın temel amacı; yalın altı sigma metodolojisiyle tekstil sektöründe süreç } \\
\text { iyileştirmeye yönelik israfların ve meydana gelen hataların tespit edilmesidir. Bunun yanı sıra; Üretim } \\
\text { Akış Zamanı, İşlem Zamanı, Birim Başına Hata Oranı ve Hazırlık Zamanı gibi değerlerde azalma olup } \\
\text { olmadığını; İlk Zaman Verimi ile Genel Ekipman Etkinliği değerlerinde ise artma olup olmadığını } \\
\text { belirlemektir. }\end{array}$ \\
\hline $\begin{array}{l}\text { Gönderilme Tarihi } 2 \\
\text { Şubat } 2021 \\
\text { Revizyon Tarihi } 9 \\
\text { Haziran } 2021 \\
\text { Kabul Tarihi } 15 \text { Haziran } \\
2021\end{array}$ & $\begin{array}{l}\text { Yöntem - Tekstil sektöründe uygulanan bu araştırmanın modeli yalın altı sigmanın tanımlama, ölçme, } \\
\text { analiz, iyileştirme ve kontrol kriterleri çerçevesinde sunulmuştur. Araştırma verileri bizzat araştırmacı } \\
\text { tarafından gözlem tekniği kullanılarak, } 2019 \text { Eylül ve } 2020 \text { Ağustos ayları arasında toplanmıştır. } \\
\text { Araştırmada yalın üretim tekniklerinden; değer akış haritalama, toplam üretken bakım, 6S, tam } \\
\text { zamanında üretim, kaizen, takt, standart iş, andon ve görsel yönetim teknikleri kullanılmışıtır. Verilerin } \\
\text { analizinde ve yorumlanmasında minitab ve excel programları kullanılmıştır. }\end{array}$ \\
\hline \multirow[t]{2}{*}{$\begin{array}{l}\text { Makale Kategorisi: } \\
\text { Araştırma Makalesi }\end{array}$} & $\begin{array}{l}\text { Bulgular - Yalın altı sigmanın Tanımlama-Ölçme-Analiz-Faz Geliştirme-Kontrol döngüsünün başarılı bir } \\
\text { şekilde uygulanması ile işletme içerisinde bulunan birçok israf ve hatalı ürün azaltılmıştır. Bu bağlamda } \\
\text { da Üretim Akış Zamanında \%75,13, İşlem Zamanında \%32,5, Hazırlık Zamanında \%12,6, Birim Başına } \\
\text { Hata Oranında \%41,2'lik bir azalmanın olduğu, İlk Zaman Veriminde \%4,4 ve Genel Ekipman } \\
\text { Etkinliğinde \%32,4'lük bir artışın olduğu bulgusuna varılmıştır. }\end{array}$ \\
\hline & $\begin{array}{l}\text { Tartışma - Sonuç olarak yalın üretim tekniklerinden tam zamanında üretim, kaizen, standart iş, } 6 \mathrm{~S} \text { ve } \\
\text { taktın uygulanması ile Üretim Akış Zamanı, İşlem Zamanı ve Hazırlık Zamanının azalması sağlanmıştır. } \\
\text { Toplam üretken bakım, andon, görsel yönetim, iş gücü eğitimi, verimlilik yönetim cihazları ve kumaş } \\
\text { kontrol makinasının sürece dahil edilmesi ile Birim Başına Hata Oranının azalması sağlanmıştır. Bu } \\
\text { bağlamda Birim Başına Hata Oranının azalması ise İlk Zaman Veriminin ve Genel Ekipman Etkinliğinin } \\
\text { artmasına sebep olmuştur. }\end{array}$ \\
\hline
\end{tabular}

\section{ARTICLE INFO}

Keywords:

Lean Manufacturing

Lean Six Sigma

Business Process

Improvement

Received 2 February 2021

Revised 9 June 2021

Accepted 15 June 2021

Article Classification:

Research Article

\section{ABSTRACT}

Purpose - The main purpose of this research is; It is the determination of waste and errors in process improvement in the textile industry with lean six sigma methodology. And also; Whether there is a decrease in values such as Production Flow Time, Processing Time, Per Unit Error Rate and Preparation Time; It is to determine whether there is an increase in the values of First Time Efficiency and General Equipment Effectiveness.

Design/Methodology/Approach - The model of this research applied in the textile industry is presented within the framework of the define, measure, analysis, improve and control criteria of lean six sigma. The research data were collected by the researcher herself, using the observation technique, between September 2019 and August 2020. Lean production techniques in research; value stream mapping, total productive maintenance, $6 \mathrm{~S}$, just in time production, kaizen, takt, standard work, andon and visual management techniques are used. Minitab and excel programs were used in the analysis and interpretation of the data.

Findings - With the successful implementation of Lean Six Sigma's IdentificationMeasurement-AnalysisPhase Improvement-Control cycle, many waste and defective products in the business have been reduced. In this context, there is a decrease of $75.13 \%$ in Production Flow Time, 32.5\% in Process Time, $12.6 \%$ in Preparation Time, $41.2 \%$ in Error Rate Per Unit, First Time Efficiency It was concluded that there was an increase of $4.4 \%$ in and $32.4 \%$ in General Equipment Effectiveness.

${ }^{1}$ Bu çalışma Mehmet Selami YILDIZ danışmanlığında Düzce Üniversitesi Sosyal Bilimler Enstitüsü'nde sunulan “Yalın Altı Sigma Metodolojisi ile Süreç İyileştirmeye Yönelik Tekstil Sektöründe Bir Uygulama" başlıklı yüksek lisans tezinden üretilmiştir. 
Discussion - As a result, production flow time, processing time and preparation time have been reduced by applying just-in-time production, kaizen, standard work, $6 \mathrm{~S}$ and takt from lean production techniques. By including total productive maintenance, andon, visual management, workforce training, productivity management devices and fabric control machine in the process, the Per Unit Error Rate was reduced. In this context, the decrease in Per Unit Error Rate has caused an increase in First Time Efficiency and General Equipment Effectiveness.

\section{GİRIŞ}

Müşteri isteklerinin sürekli değiştiği model değişikliğinin giderek artıp üretim sayılarının azaldığı küresel rekabet koşullarında hazır giyim işletmelerinin hayatta kalabilmesinin en büyük şartı daima en önde yer alabilmelerine bağlıdır. Bunu başarabilmenin yolu ise dönemin yapısına uyum sağlayabilmek ve yeniliklere açık olabilmekten geçmektedir. Bu yüzden hazır giyim endüstrisinde faaliyette olan işletmeler rekabet ortamında daha çok gelişebilmek için model çeşitliliğini arttırarak daha az sayıda, daha kısa sürede, daha kaliteli ve daha ucuz ürünler üretmek durumundadırlar. Son zamanlarda gelişmiş olan ülkelerde gelir düzeyinin yükselmesi ile birlikte müşteri beklentileri artmış, tüketiciler sürekli yenilik arar hale gelmişlerdir (Eser ve Yıldız, 2018:1). Bu noktada küreselleşme olgusuyla karşılaşan işletmeler uluslararası düzeyde düşünmek ve buna göre hareket etmek zorundadırlar. Yalın altı sigmanın amacı işletmelerde toplam maliyeti arttıran ve ürünün verimliliğini gösteren israfı ortadan kaldırarak belirlenen zaman aralığında en az kaynak kullanımıyla ürünleri düşük fiyattan daha kaliteli ve hatasız bir şekilde müşteriye teslimini sağlayabilmektir. Bu işlem bir ürünün tasarımından başlayıp en son aşaması olan müşteriye ulaşmasına kadar ki tüm sürecin iyileştirilmesidir. Bu noktada işletmeler hazır giyim sektöründe ayakta kalabilmek ve varlıklarını devam ettirebilmek için yalın altı sigma yöntemine ihtiyaç duymaktadırlar.

Dünya ekonomisine büyük oranda değer sağlaması ve ülkelerin kalkınmasında büyük öneme sahip olması sebebiyle hazır giyim sektörü insanlık var olduğu sürece devam edecek bir sektördür. Fakat küreselleşme ile birlikte modanın değişmesine bağlı olarak model sayılarının artıp sipariş sayılarının düşmesi tekstil sektörünü daha karmaşık bir yapı haline getirmiştir. Bu da beraberinde işletmede makinelerin ayar değişikliklerini ve hatalı üretimin oluşmasına sebep olmuştur. Karşılaşılan bir diğer büyük problem ise bir ürünün tedarikçiden başlayıp müşteriye ulaşma süresinin uzun ve israflarla dolu olmasıdır. İşletmeler bu süreçteki uzun üretim sürelerini azaltıp israflardan süreci arındırarak yalın bir üretim sistemi oluşturmak için çalışmak durumundadır. Bu çalışma da nitel yöntem ile tekstil sektörü içerisinde yalın altı sigma metodolojisi ile israfların ve üründe meydana gelen hataların değerlendirilmesi amaçlanmaktadır. Bu amaç doğrultusunda ise üretim akış zamanı, işlem zamanı, birim başına hata oranı (DPU) ve hazırlık zamanı değerlerinde azalmanın olup olmadığı; ilk zaman verimliliği (FTY) ile genel ekipman etkinliği (OEE) değerlerinde ise artmanın olup olmadığı tespit edilecektir. Çalışmanın ikinci bölümünde yalın altı sigma metodolojisi ve tekstil sektöründe DMAIC (Define- Measure-Analysis- Improve- Control) (Tanımla- Ölç- Analiz et- Geliştir- Kontrol et) döngüsü incelenmiştir. Üründe meydana gelen hataların ve işletmedeki israfların değerlendirilmesi yapılmıştır. Son bölümde ise sonuç ve önerilere değinilmiştir. Bu noktada çalışmada kullanılan araştırma tekniği nitel araştırma yöntemidir. Nitel araştırma yöntemlerinden gözlem tekniği kullanılarak üretim sürecinde birebir gözlem yapılarak analiz ve sonuçları elde edilmiştir. Literatür incelendiğinde tekstil işletmelerinde yalın altı sigma ile ilgili çok az sayıda çalışma yapıldığı görülmüştür. Tekstil sektörü ile ilgili daha önce yapılan çalışmalarda sadece yalın üretim teknikleri kullanıldığı görülmüştür. Bu araştırma ile literatürdeki boşluk doldurulmak istenmiştir.

$\mathrm{Bu}$ araştırmanın evreni, Düzce ilinde bulunan bir hazır giyim firmasında gerçekleştirilmiş olup elde edilen veriler 2019 ve 2020 yıllarında kumaş depo, aksesuar depo, kesimhane, dikimhane, paketleme, kalite güvence ve lojistik bölümlerinden alınarak analiz edilmiştir. Yapılan araştırma boyunca tüm ürünlerin gözleminin gerçekleştirilemeyeceğinden dolayı bir ürün ailesi seçilmiş ve bu örneklemin evreni yansıttığı varsayılmıştır.

\section{KAVRAMSAL ÇERÇEVE}

\subsection{Yalın Altı Sigma}

Yalın üretim kavramı işletmelerde değer katmayan unsurlara odaklanarak ürünün tedarikçiden müşteriye teslimine kadar ki her aşamasında israfın ortadan kaldırılması için tasarlanmıştır (Çelebi ve Yıldız, 2020). Altı sigma kavramı ise ürün üzerindeki değişkenliği azaltmak, kusurları gidermek için bir disiplin sağlayan proje odaklı, istatistiksel temelli bir yaklaşım olarak tanımlanmıştır (Montgomery ve Woodall, 2008). Altı sigma aynı 


\section{G. Çelebi Gürsoy - M. S. Yıldız 13/2 (2021) 1553-1573}

zamanda nedenleri belirlemeyi ve ortadan kaldırmayı amaçlayan bir iş geliştirme stratejisidir (Drohomeretski vd., 2014). Bu noktada yalın altı sigma metodolojisi yalın üretim ve altı sigma olan iki kalite yönetimi kavramının bütünleşmesi olup, her iki kavram tarafından da elde edilen iyileştirmelerin kapsamını ve boyutunu arttırmaya çalışan bir yöntemdir (Ajmera vd., 2017). Yalın ve altı sigma kavramlarının birleşik gücünün tanınması üzerine, yalın altı sigma tekniği 1990'lı yıllarda araştırmacılar tarafından ortaya atılmıştır (Thomas vd., 2009). Geniş bir uygulama alanı olan yalın altı sigma kavramı yalın ve altı sigmanın kritik boşluklarını ve eksikliklerini kapatan yapılandırılmış bir sürekli iyileştirme yöntemidir (Sunder vd., 2020).

Yalın altı sigma, süreç performansını arttırmak, yüksek kalite ve düşük değişkenlik seviyeleri elde etmek için geliştirilmiş olan bir yaklaşımdır (Ma, 2014). Bir başka ifadeyle yalın altı sigma, müşteri bakış açısıyla, değeri tanımlayan, israfı yok ederek kalite, hız ve maliyete odaklanan, değişkenliği azaltmayı amaçlayan, tüm çalışanların katılımını sağlayan ve temel hedefi müşteri memnuniyeti olan bir yönetim felsefesidir (Akgül, 2019). Yalın altı sigma kavramı aynı zamanda yalın üretim ve yalın yönetimi destekleyen ve tüm uygulamalarla altı sigma performansını yakalamayı amaçlayan bir yöntemdir (Günday, 2019). Yalın altı sigma metodolojisi, belirli iş sorunlarına ve araçların uygulanmasına yanıt vermek ve bunları ele almak için yalın bilgi birikimini kullanmaktadır (Gupta, vd., 2020). Yalın altı sigmanın uygulanması, hatasız ve kesintisiz üretim gibi faydalar sağladığı gibi daha yüksek derecede rekabet edebilirliğin elde edilmesini sağlamaktadır. (Vinodh vd., 2011). Bu iki önemli metodolojide kullanılan bazı teknikler bulunmaktadır (Vinodh vd., 2011, Kumar vd., 2006).

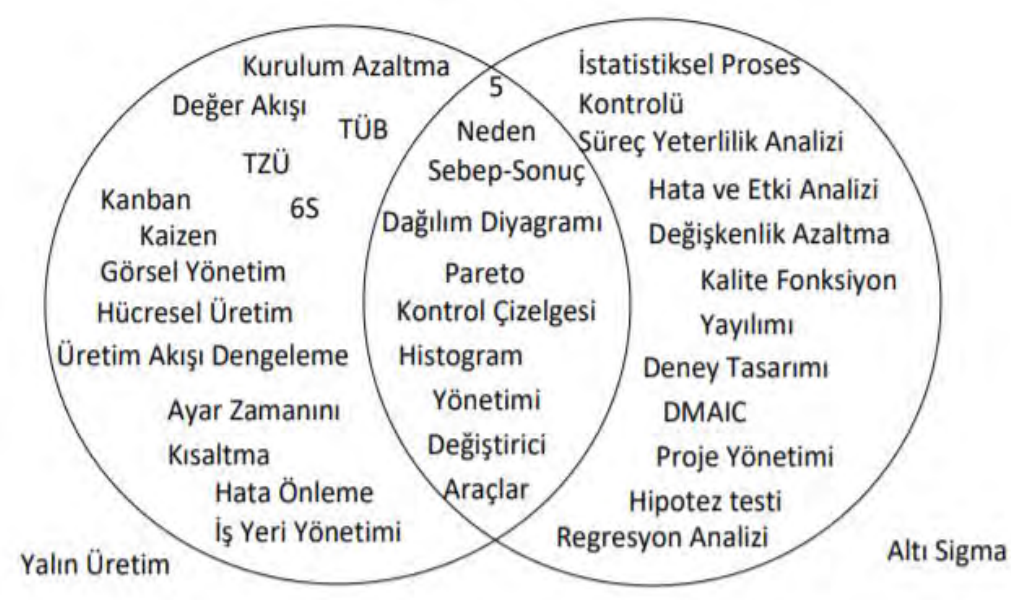

Şekil 1. Yalın ve Altı Sigma'da Kullanılan Araçlar

(Kaynak: Vinodh vd., 2011: 711, Kumar vd., 2006: 409).

Şekil 1 incelendiğinde yalın üretim ve altı sigma kavramların da kullanan teknikler ve kesişim kümesinde bulunan teknikler gösterilmiştir.

\subsection{Yalın Altı Sigma'da Kullanılan Araçlar}

\subsubsection{Tanımlama (Define) Aşaması}

Tanımlama aşaması DMAIC döngüsünün ilk aşaması olması nedeniyle problemin tanımlanması, proje tüzügü ve oluşturulmasını kapsamaktadır. Tanımlama aşaması sayesinde işletme ve problem hakkında genel bilgiler sağlanmaktadır. Ayrıca tanımlama aşaması problem ifadesinin geliştirilmesine, ekibin sorunları netleştirmesine ve ölçülebilir bir sonuç belirlenmesine yardımcı olmaktadır (Baker vd., 2020).

\section{- Problem Tanimı}

Problem tanımlama da müşteriyi iyi tanımak oldukça önemlidir. Bu yüzden problem tanımlama kısmı müşterilerden alınan dönütlere göre yapılmakta ve işletmede iyileştirmeler buna göre oluşturulmaktadır. Bu noktada bir dizi beyin fırtınası yapılarak ekip üyeleri tarafından problem tanımlanabilmektedir (Kumar vd., 2006). 


\section{- Proje Tüzü̈̆̈̈}

Proje tüzüğü bir projenin kapsamı, amaçları ve katılımcıları ve bu katılımcıların görev ve sorumluluklarını içeren bir tablodur. Ayrıca projenin kapsamına ve proje hedeflerinin belirlenmesine yardımcı olan unsurların belirlenmesine yardımcı olmaktadır (Furterer,2016:14).

\section{- Mevcut Durum Haritası}

Mevcut durum haritası adından da anlaşılacağı gibi mevcut üretim sistemindeki süreçler boyunca materyallerin ve bilginin nasıl aktığını gösteren bir tekniktir (Singh, J. vd., 2019). Aynı zamanda yalın üretim tekniği olan bu haritalama ile tüm akışın takibinin zor olacağından ilk önce bir ürün ailesinin seçilmesi gerekmektedir.

\subsection{2. Ölçme (Measure) Aşaması}

Müşterinin ihtiyaçlarını karşılamak için sürecin ölçülmesi, bir veri toplama planı geliştirilmesi ve sorunları belirlemek için verilerin karşılaştııılması gerekmektedir (Sánchez-Rebull vd., 2020). Aynı zaman da bu aşamada müşteriye sunulacak ürünün kalitesi ve ölçümleri için kritik olan faktörler de belirlenmektedir (Vinodh vd., 2011).

\section{- Veri Koleksiyonu}

Bir ürünün ham maddesinden başlayıp müşteriye ulaşıncaya kadar ki süreçteki verilerin sistematik ve düzenli şekilde toplanmasıdır. Veri toplama herhangi bir deneysel literatür taraması araştırması için önemli bir adımdır (Henrique ve Godinho Filho, 2020). Bu veriler çevrim zamanı, hazırlık zamanı, çalışma süresi, çalışan sayısı ve süreçler arası stok ile bekleme zamanları gibi daha çok zaman bazlı oluşturulmuş verilerdir.

\section{- İsraf Kategorizasyonu}

İsraf kategorizasyonu üretimde meydana gelen israfların sınıflandırılması işlemidir. Nitekim yalın üretimin ana prensibi israfları tanımlamak ve ortadan kaldırmaktır. Bu israflar, fazla üretim, aşırı işlem, taşıma, ikinci işçilik hareket, bekleme, envanter ve yetenek/fikir kaybı şeklindedir (Kaswan ve Rathi, 2020).

\section{- Aktivite Kategorizasyonu}

Aktivite kategorizasyonu olarak adlandırılan şey süreç içerisinde değer katan, değer katmayan ve zorunlu değer katmayan faaliyetlere dayalı bir aktivite tanımlama sürecidir. Aktivite kategorizasyonu, tüm süreçteki değer katmayan faaliyetlerin yüzdesinin belirlenmesine yardımcı olmaktadır. (Prasanna ve Vinodh, S. 2013).

\subsubsection{Analiz (Analyze) Aşaması}

Bu aşamada önemsiz nedenlerin karmaşıklığından sıyrılmak için kapsamlı veri analizi yapılarak daha spesifik bir veri analizi oluşturulmaktadır. Bu noktada süreç içerisinde değişikliklere ve gecikmelere neden olan her faktörü tanımak için analiz aşamasının uygulanması gerekmektedir (Ricciardi vd., 2020). Aynı zaman da burada tanımlanan problem çerçevesinde oluşan hataların tespit edildiği bir veri analizi yapılarak Pareto analizi oluşturulmaktadır. Oluşturulan bu pareto analizden yola çıkarak kök neden ulaşmak için neden sonuç şeması olarak adlandırılan balık kılçı̆̆ı diyagramı oluşturulmaktadır.

\section{- Pareto Analizi}

ABC analizi olarak da bilinen Pareto diyagramı, 19. yüzyılda İtalyan Vilfredo Pareto tarafından ortaya çıkarılmıştır (Eser, 2018). Ana mantığı işletme içerisinde çıkan sorunların \%80'inin, nedenlerin \%20'sinden kaynaklandığı yönündedir (Ata vd., 2020). Bu durum nedenlerin \%20'lik kısmı eğer çözülürse sorunun \%80'nin çözüleceği anlamına gelmektedir.

\section{- Sebep-Sonuç Diyagramı (Balık Kılçı̆̆ı Diyagramı)}

Kalite araçlarından biri olan sebep-sonuç diyagramı balık kılçı̆̆ı diyagramı ya da 1943 yılında Kaoru Ishikawa tarafından bulunması sebebiyle Iskikawa diyagramı olarak da bilinmektedir. Sebep ve sonuç diyagramı, bir sorunun olası nedenlerini kategorize etmek ve fikirleri yararlı kategorilere ayırmak için kullanılan bir araçtır (Uluskan ve Oda, 2020). 


\subsubsection{Faz Geliştirme (Improvement) Aşaması}

Belirlenen kök nedenlerden sonraki adım çözümlerin kişiler tarafından üretilip test edileceği iyileştirme aşamasıdır. Burada tanımlama aşamasında yapılan mevcut durum haritasında iyileştirmeler yapılarak gelecek durum haritasında bunların gösterilmesi ve pareto diyagramında belli edilen sebeplerin doğrulanması gerekmektedir.

\section{- Gelecek Durum Haritası}

Mevcut durum haritasının analizinden, gelecekteki bir durum haritası ve ardından israf azaltımı için Kaizen projelerini içeren uygulama planı çizilmektedir (Chiarini ve Kumar 2020). Asıl amacı ürünün hammadde ile müşteri arasında geçirmiş olduğu o zaman dilimi arasını iyileştirerek betimlenmesini sağlamaktır. Aynı zamanda üretimde kullanılması istenilen yalın üretim uygulamaları gelecek durum haritasında gösterilmektedir.

\subsubsection{Kontrol (Control) Aşaması}

Son aşama ise kontrol aşamasıdır. Müşterilerin gereksinimlerinin karşılanması için süreç varyasyonlarının kontrol edilmesi, sürecin izlenmesi ve kontrol etmek için bir stratejinin geliştirilmesi gerekmektedir (SánchezRebull vd., 2020). Bu aşamada tanımlanan ve uygulanan iyileştirmelerin belgelenmesi ve sürekliliğinin sağlanması için kontrol mekanizmaları oluşturulmaktadır.

\section{- Kontrol Grafiği}

Kontrol grafikleri, bir sürecin zaman içindeki performansını gözden geçirmek için sürecin kontrollü ve kararlı olup olmadığını, normal şekilde işleyip işlemediğini veya performansı etkileyecek olan şeylerin değişip değişmediğini belirleyen bir araçtır (Antony, 2020).

\section{- Sürdürülebilirlik Planı}

Üretim süreci içerisinde iyileştirmeler yapılarak hataların azaltılıp maliyet unsurlarının azaltılarak sürdürülebilirliğin sağlanması işletme için oldukça önemlidir. Bu yüzden, optimum işlem parametreleri ayarının standardizasyonu ve sürdürülebilirliği gereklidir (Kumar vd., 2006). Sürdürebilirliğin sağlanması için takip edilmesi gereken bazı parametreler vardır. Bunun ile ilgili denklemler aşağıda verilmiştir (Swarnakar ve Vinodh 2015).

\footnotetext{
Birim başına hata $($ DPU) $=$ Bulunan Hataların Sayıs $/ /$ Üretilen Birim Sayısı

İlk zaman verimi $(\mathbf{F T Y})=e^{-D P U}$
}

Genel ekipman etkinliği (OEE) $=A * E * Q(A$, Makinenin kullanılabilirliği; E, Performans oranı; $Q$, Kalite oranı veya ürünün verimi)

Kullanılabilirlik $=\frac{\text { Toplam vardiya süresi } * \text { Çalışma günü sayısl-Planlanmamış saatler }- \text { Toplam Kayıp }}{\text { Toplam vardiya süresi } * \text { Çalışma günü sayısl-Planlanmamış saatler }}$

$$
\begin{gathered}
\text { Performans }=\frac{\text { Çevrim süresi } * \text { Üretilen ürün }}{\text { Toplam vardiya süresi } * \text { Çalışma günü sayısl-Planlanmamış saatler }} \\
\text { Kalite }=\frac{\text { Üretilen Miktar }- \text { Reddedilen miktar }}{\text { Üretilen miktar }}
\end{gathered}
$$




\section{YÖNTEM}

\subsection{Araştırmanın Modeli ve Temel Hipotezi}

Araştırmanın kavramsal modeli Şekil 2'deki gibidir. Tekstil sektöründe uygulanan bu araştırma yalın altı sigmanın tanımlama, ölçme, analiz, iyileştirme ve kontrol kriterleri çerçevesinde sunulmuştur. Ayrıca her bir kritere ait alt başlıklar da araştırmaya katkı sağlamıştır.

“Hı: Yalın altı sigma metodojisinin uygulanmasının; üretim akış zamanı, işlem zamanı, birim başına hata oranı, hazırlık zamanı, ilk zaman verimi ve genel ekipman etkinli üzerinde istatistiksel olarak anlamlı pozitif bir etkisi vardır".

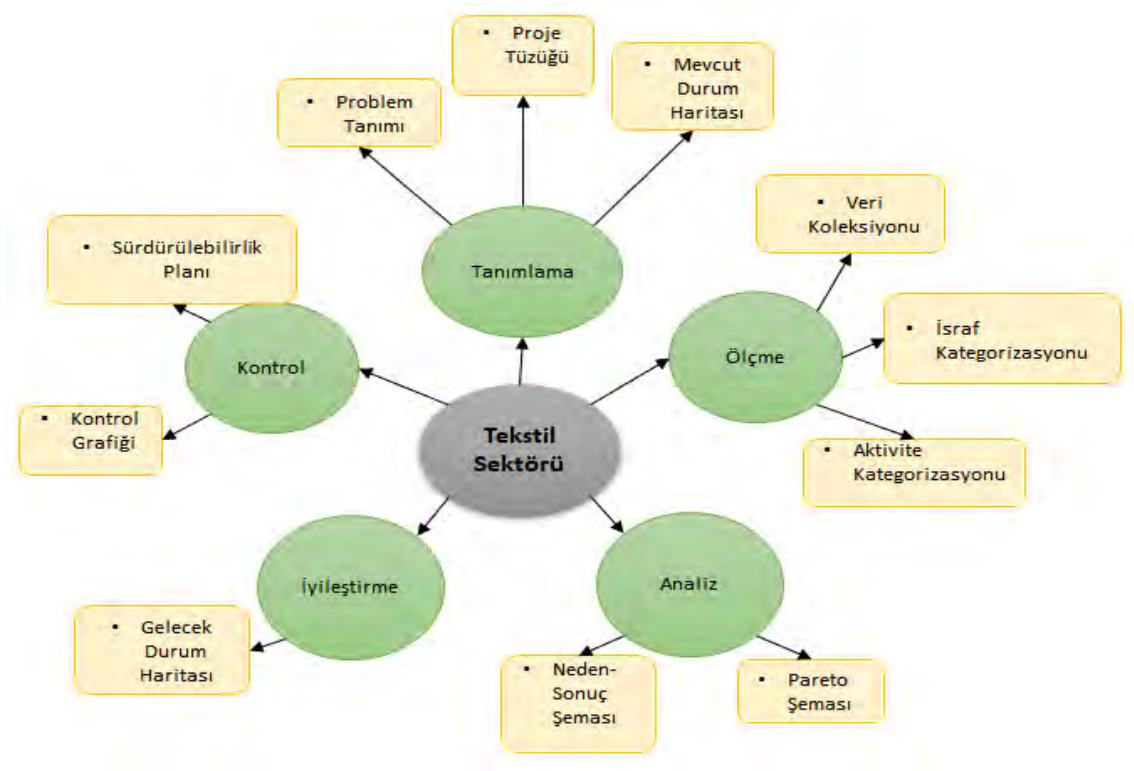

Şekil 2. Araştırmanın Kavramsal Modeli

\subsection{Araştırmanın Evren ve Örneklemi}

Araştırmanın evreni Düzce ilinde 2008 yılında kurulan ve Belçika'ya ihracat yapan bir hazır giyim firmasıdır. Araştırmanın örneklemi ise bire bir araştırmacı tarafından firmanın kumaş depo, aksesuar depo, kesimhane, dikimhane, paketleme, kalite güvence ve lojistik bölümlerinden kronometre ile alınan verilere göre oluşturulmuştur. İşletmede 2020 yılının verilerine göre 20 beyaz yaka 200 mavi yaka olmak üzere 220 çalışan bulunmaktadır.

\subsection{Veri Toplama Aracı ve Verilerin Toplanması}

Araştırma verileri bizzat araştırmacı tarafından gözlem tekniği kullanılarak, 2019-2020 tarihleri arasında toplanmıştır. Gözlem, sistematik olarak neyi aradığını bilen ve tanımlanmış bir yaklaşımla, çizelgeler ve ölçekler kullanılarak bir oluşumu, göz dâhil duyularla izleyerek yapılan veri toplama tekniğidir (Kozak, 2001). Bu çalışmada araştırmacı gözlemlenecek olay ve süreçleri belirledikten sonra ne zaman ve ne şekilde gözlem yapacağına karar vermiştir. Bununla birlikte, tekstil sektöründe yalın uygulamalar üzerinde çalışmalar yapan uzman kişilerin de görüşleri bizzat alınarak, araştırmacı tarafından önceden gözlem yönteminde kullanılmak üzere çizelgeler ve ölçek formları oluşturulmuştur. Bu çizelge ve formlar araştırmanın bulgular bölümünde gösterilmiştir. Gözlem seçilen ürün ailesinin prosesler boyunca akışı sürecinde ve 381 adet ürün için gerçekleşmiştir.

\subsection{Verilerin Analizi}

Araştırmanın analiz bölümünde yalın altı sigmanın DMAIC döngüsünün oluşturulması için her aşamada ayrı bir çalışma yapılmıştır. İlk olarak sürecin analizinin sağlanması ve işletmede bulunan israfların değer katan ve değer katmayan faaliyetlerin tespit edilmesi için yalın üretim tekniklerinden değer akış haritalama tekniği 


\section{G. Çelebi Gürsoy - M. S. Yıldız 13/2 (2021) 1553-1573}

uygulanmış ve mevcut durum haritası oluşturulmuştur. İkinci olarak ise hata oranlarını azaltmak için birtakım analiz metotları uygulanmıştır.

Araştırma kapsamında değer akış haritalama tekniği işletmede ürünün hammaddesinden müşteriye ulaşıncaya kadar ki tüm süreç için oluşturulmuştur. Bunun için kronometre ile her operasyon için etüt alınarak gözlem yapılmış ve operatörlerin ürünü ne kadar sürede üretebildiği ile ilgili veriler toplanmıştır. Daha sonra karşılaşılan sorunlar not edilmiş operasyon bazlı değer katan ve değer katmayan faaliyetler tespit edilip departmanların değer yüzdeleri oluşturulmuştur. Daha sonra problemler ve iyileştirme noktaları belirlenerek gelecek durum haritası çizilip yeni akışın nasıl olması gerektiği tasarlanmış ve sonra uygulama planına geçilmiştir. Buradaki ana amaç israfları azaltmak ve değer katan faaliyetleri mümkün olduğunca arttırmaktır. İşletme de ki hata oranlarını azaltmak için ilk önce hataların en çok neyden kaynaklı olduğunu bulmak gerekmektedir. Bu yüzden araştırmanın bulgular bölümünde anlatılan pareto analizi ile işletme içerisindeki hataların büyük kısmının neyden kaynaklandığı saptanmıştır. Daha sonra da bu hataların sebebinin ne olduğu neden-sonuç şemasında açık bir şekilde gösterilmiştir.

\section{BULGULAR}

\subsection{Firmanın Tanımı}

Hazır giyim firması olan işletme merkez ofis, modelhane ve atölye olarak 2003 yılında İstanbul'da kurulmuştur. İlk kurulduğu yıllarda bu tekstil firması, gelirini değişik markalara fason üretim yaparak sağlamaktaydı. Daha sonra 2017 yılında üretimini yaptığı ünlü bir markayı satın alarak, üretimden satışa kadar markayı Türk markası yapmıştır. 2017'den bu zamana kadar da bu markaya ihracat yapmaktadır. Marka 1994 yılında Belçika' da kurulmuş olup bebek giyimden yetişkin giyime kadar her yaş grubuna hitap eden kimliğiyle dikkat çekmektedir. Belçika'da 350 müşterisi, Türkiye'de kendi bünyesine ait 4 mağazası bulunan firma 2008 yılı Ekim ayında Düzce ilinde faaliyete başlamış bir ihracat firmasıdır. Düzce ilinde bulunan firmanın 220 çalışanı bulunan işletme 7.000 metre karelik açık alana 18.000 metre karelik ise kapalı alana sahiptir. Ayrıca kendi markasına hizmet ettiği günden bugüne kendi tasarımını kendi yapmaktadır. Firma müşteri istek ve beklentilerini en iyi şekilde kendisine ilke edinmiştir. Aynı zamanda işletme kendine özgü kurum kültürünü oturtmuş ahlaki değerlere önem veren ve çalışanlarına büyük değer veren bir firma profilindedir. Tekstil sektöründeki vizyonunu ve deneyimini perakende sektörüne de yansıtan marka kurulduğu ilk andan beri kaliteli ürünleri, özenli hizmet anlayışı, yenilikçi ve araştırmacı ürün üretme anlayışıyla hizmet vermeye devam etmektedir.

\section{2. İşletmede Yalın Altı Sigma ile İlgili Yapılan Çalışmalar}

Yapılan yalın altı sigma çerçevesi, orta ölçekli bir tekstil işletmesinde uygulanmıştır. Çalışmanın yapıldığı tekstil endüstrisinde pijama, tulum, gecelik, mayo, bornoz, havlu, çamaşır vb. çeşitli ürünler üretilmektedir. Bu noktada yönetim yalın altı sigmayı uygulamak istemektedir çünkü işletme içerisinde bulunan israfları ve üründe meydana gelen hataları mümkün olduğunca üretim sürecinden uzaklaştırmak istemektedir. Yalın altı sigma uygulaması için önerilen çerçeve aşağıda ayrıntılı olarak anlatılmıştır. Çerçeve, üretim sürecinin tüm düzenini gözlemleyip veriler topladıktan sonra yöneticiler ve çalışanlar ile görüşmeler yapılarak geliştirilmiştir. Bu noktada üretim sürecinin verimlilik yüzdesini geliştirmek için DMAIC problem çözme metodolojisi kullanılmıştır. Yalın ve altı sigma iş stratejilerinin entegre yaklaşımında kullanılan araçlar, teknikler ve ilkeler DMAIC döngüsü içerisinde anlatılmıştır.

\subsubsection{Tanımlama (Define) Aşaması}

Tanımlama aşaması DMAIC döngüsünün ilk aşaması olması nedeniyle problemin tanımlanması, süreçlerin akış şemasının oluşturulması, mevcut durum haritasının oluşturulması, proje tüzügü ve SIPOC şemasının oluşturulmasını kapsamaktadır. Bu aşama sayesinde işletme ve problem hakkında genel bilgiler sağlanmaktadır.

\section{- Problem tanımı}

Müşteri sesine dayalı olarak kritik kalite özelliklerini belirlemek için işletmede iki kez beyin fırtınası toplantıları gerçekleştirilmiştir. Toplantıya üst yönetim ve orta yönetimden olmak üzere toplam beş çalışan katılmıştır. Bunun neticesinde üretim sürecinin problemi, problemin büyüklüğü, problemin etkisi vb. durumlar ekip üyeleri arasında tartışılmıştır. Ve iki büyük problem saptanmıştır. Birincisi üretim sürecinin 


\section{G. Çelebi Gürsoy - M. S. Yıldız 13/2 (2021) 1553-1573}

israflarla dolu ve uzun olmasıdır. İkincisi ise ürün de meydana gelen hatalardır. İşletme bu problemleri yalın altı sigma yöntemi ile çözmeyi amaçlamaktadır.

\section{- Proje Tüzüğ̈̈}

Proje tüzüğü, bir projenin kapsamı, amaçları ve katılımcılarının bir beyanıdır. Tablo şeklinde gösterilen proje çalışma planının bir ifadesidir. Ayrıca projenin başlangıç ve bitiş tarihlerini tanımlayarak araştırmacıya rol haritası çizmektedir. Bu çalışmaya karşılık gelen proje tüzügü hazırlanmış olup ve Tablo 1 'de gösterilmiştir.

Tablo 1. Proje Tüzüğü

\begin{tabular}{llll}
\hline Ürün/Hizmet & Pijama & X Hazır Giyim İşletmesi & PLC Üst/PLC Alt \\
\hline Uzman & Bay X & Ürün Müşterileri & X Müşterisi \\
\hline & Bay Y & Takım Üyeleri & Tüm çalışanlar \\
\hline Koordinatör & Bayan Z & Tamamlanma Tarihi & 24.08.2020 \\
\hline Şampiyon & Bayan A & & \\
\hline Başlangıç Tarihi & 17.09 .2019 & & \\
\hline Bileşen & Açıklama & $\begin{array}{l}\text { Verimlilik yüzdesini etkileyen üründe hatalara yol açan kusurların ve değer katmayan } \\
\text { faaliyetlerin belirlenmesi. }\end{array}$ & \\
\hline \multirow{5}{*}{ Problem } & Süreç içerisindeki israfların ve üründe meydana gelen hataların değerlendirilmesi ile \\
& birlikte işlem zamanı, hazırlık zamanı, üretim akış zamanı, DPU değerlerinde azalma \\
olup olmadığı; FTY ve OEE değerlerinde artma olup olmadığının tespit edilmesi
\end{tabular}

\section{- Mevcut durum haritası}

Mevcut durum haritası, iyileştirme fırsatlarının tanımlanması ve işletmenin şu anki durumunu daha iyi anlayabilmek için ürünün hammaddeden müşteriye teslimine kadar ki sürecinin incelenip analiz edilmesiyle oluşturulmuştur. Üretim hattındaki tüm ürünlerin takibinin imkânsızlığından dolayı ürün ailesi seçilmiş ve sadece bu ürünün takibi yapılmıştır. Model seçimi yapılırken yönetim ekibi ile hangi modelin seçilmesinin daha uygun olacağı konusunda görüşmeler yapılmıştır. Bu noktada seçilen modelin işletme için daha spesifik bir ürün olması ve termin zamanının yakın olması projeye bir an önce başlanılması için çok önemlidir. Mevcut durum haritasını geliştirmenin ilk adımı, üretim hattının tüm iş akışı sürecini incelemek ve her iş istasyonundan geçen malzeme akışının şematik bir diyagramını oluşturmaktır.

Mevcut durum haritasını geliştirmek için gereken veriler çevrim süresi, hazırlık süresi, çalışan sayısı, beklemeler, stoklar, üretim akış süresi ve işlem süresidir. Bu veriler her sürecin altında listelenmiştir. Mevcut durum haritası Şekil 3 ve 4'deki gibidir. Ürün alt ve üst olmak üzere iki parçadan meydana gelmektedir. Proseslere giriş-çıkış zamanları farklı olduğu için mevcut durum haritası iki ayrı ürün gibi oluşturulmuştur. 


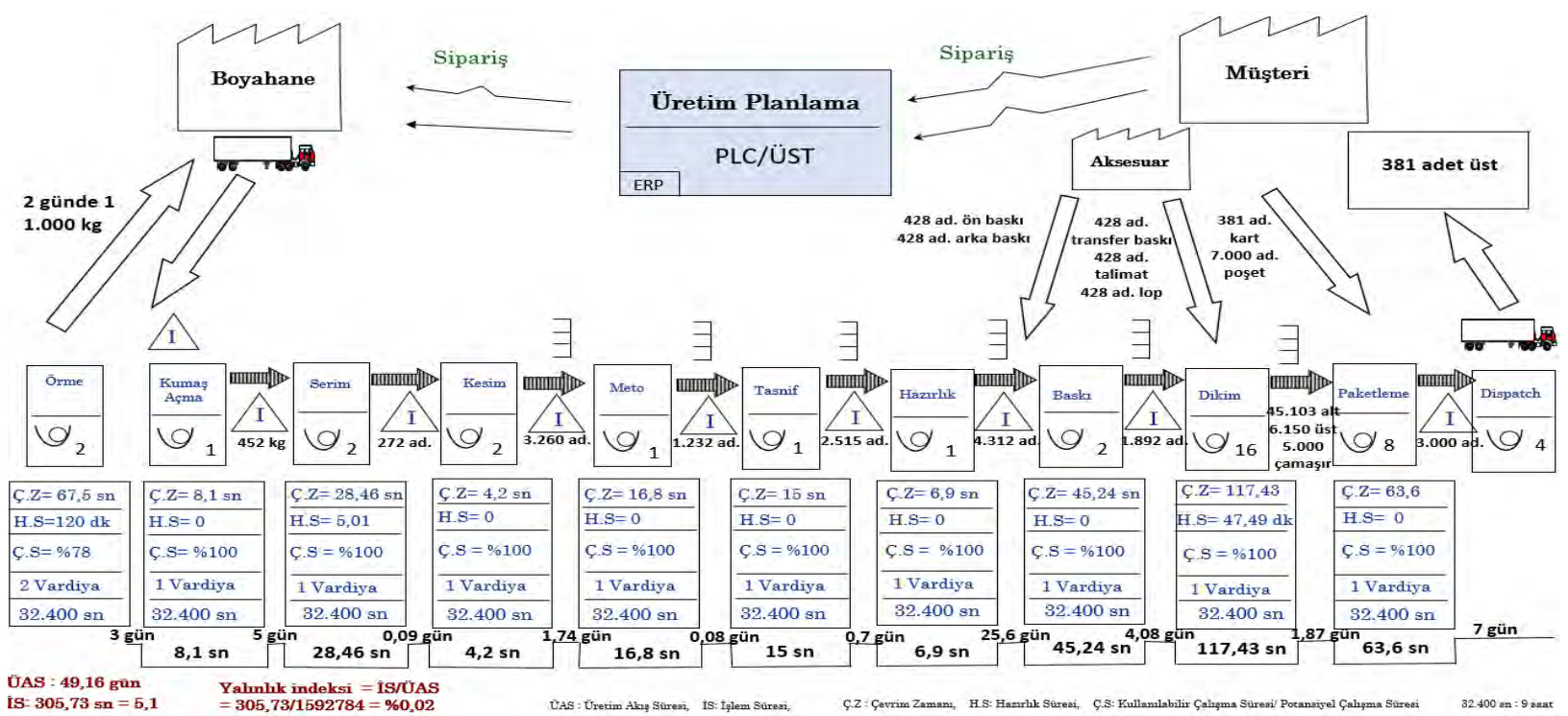

Şekil 3. Takım Üst İçin Mevcut Durum Haritası

Şekil 3 incelendiğinde iki parça olan ürünün üst kısmına ait veriler görülmektedir. Ürünün kumaş depoya gelmesinden müşteriye teslimine kadar geçen süreç üretim akış süresi olarak tanımlanmaktadır. Takım üst için üretim akış süresi 49,16 gün (1.592.784 sn), işlem süresi ise 304,82 saniyedir. Bu noktada yalınlık indeksi işlem süresinin üretim akış süresine oranlanmasıyla bulunmaktadır. Takım üst için yalınlık indeksi \%0,02'dir. Aynı zaman da bu işletmenin \%99,98'inin değer katmayan faaliyetlerden oluştuğunu göstermektedir.

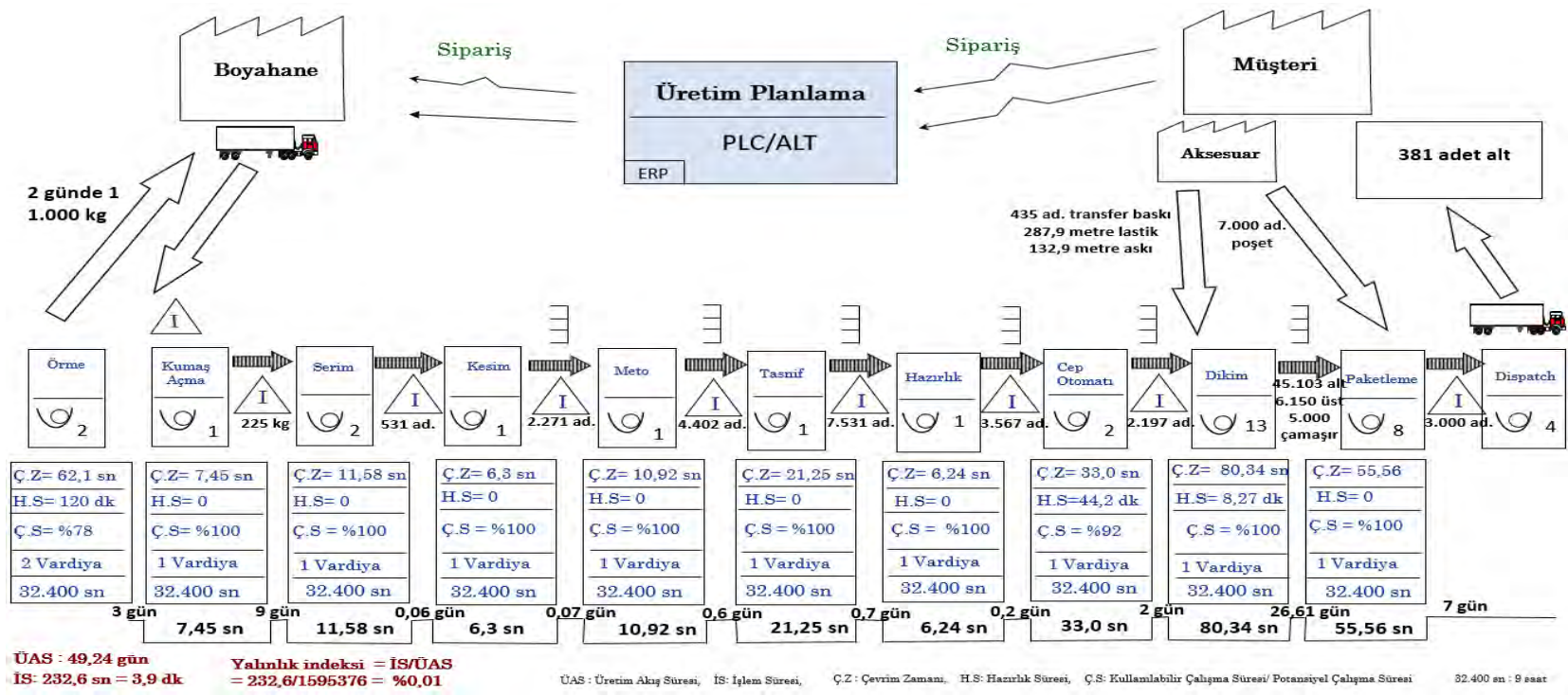

Şekil 4. Takım Alt İçin Mevcut Durum Haritası

Şekil 4 incelendiğinde ise takım alt için üretim akış süresi 49,24 gün (1.595.376 sn) işlem süresi ise 230,64 saniye olarak belirlenmiştir. Yalınlık indeksi \%0,01 olarak bulunan takım alt üretiminin \%99,99'unun değer katmayan faaliyetlerden meydana geldiği saptanmıştır. Bu noktada oluşturulacak olan gelecek durum haritasıyla süreçte meydana gelen değer katmayan ve israf olarak tanımlanan faaliyetlerin elimine edilmesi amaçlanmaktadır.

\subsection{2. Ölçme (Measure) Aşaması}

Yalın altı sigmanın ölçme aşamasında veri koleksiyonu, israf kategorizasyonu ve aktivite kategorizasyonu olmak üzere üç başlık altında çalışmalar yapılmıştır.

\section{- Veri Koleksiyonu}

Bu adımda, mevcut durum haritasının inşası için gerekli veriler, farklı iş istasyonlarındaki operatörlerle etkileşime dayalı olarak toplanmıştır. Her işlem için çevrim zamanı, hazırlık süresi, çalışan sayısı, stoklar, beklemeler ile ilgili veriler sistematik ve düzenli bir şekilde toplanıp kaydedilmiştir. 


\section{- İsraf Kategorizasyonu}

Yalın üretim, iş performansını artırmak için israfı tanımlamayı ve ortadan kaldırmayı amaçlar. İsraf kategorizasyonunun temel amacı, kusurların çoğunluğunun etkilerini uygun kategoriden gözlemlemektir. Bu bağlamda işletmede meydana gelen israflar ve etkileri Tablo 2'de analiz edilmiştir. Bu israflar araştırmacı tarafından üretim sahasında bizzat araştırma sürecinde gerçekleşmiştir.

Tablo 2. İsraf Kategorizasyonu

\begin{tabular}{ll}
\hline İsraf Türü & Etkileri \\
\hline Fazla Üretim & Gereksiz Stok, Ekonomik Kayıp \\
\hline Aşırı İşlem & Makine ve Ekipmanların Aşırı Kullanımı \\
\hline Taşıma & Lojistik Kayıp, Parça Kaybı, Üründe Deforme \\
\hline İkinci İşçilik & Zaman kaybı, Müşteri Sadakati Kaybı, Maliyet Arttırıcı Etki \\
\hline Hareket & Zaman Kaybı, Çaba Kaybı \\
\hline Bekleme & Uzun Üretim Süresi, Artan Üretim Maliyeti \\
\hline Envanter & Deponun Aşırı Kullanımı, Maliyeti Stoka Bă̆lama \\
\hline Yetenek/Fikir Kaybı & İnsan Becerileri Zaman ve Fikir Kaybı \\
\hline
\end{tabular}

\section{- Aktivite Kategorizasyonu}

Aktivite kategorizasyonu, süreç içerisinde değer katan ve değer katmayan aktivitelere dayalı bir faaliyet tanımlama sürecidir. Yapılan çalışmada kesimhane, dikimhane, paketleme bölümlerinde gerçekleşen tüm operasyonlar, değer katan aktiviteler ve değer katmayan aktiviteler olarak kategorize edilmiştir. Bu nokta da bölümlerinin değer yüzdeleri aşağıda verildiği gibidir. Yapılan iyileştirmeler neticesinde amaç değer katmayan faaliyetleri mümkün olduğunca süreçten uzaklaştırmaktır.

Tablo 3. Kesimhane Bölümünde Değer Katan ve Değer Katmayan Aktiviteler

\begin{tabular}{|c|c|c|}
\hline Proses & Operasyon & $\begin{array}{l}\text { Değer Katan/ } \\
\text { Değer Katmayan }\end{array}$ \\
\hline Serim & En boy ölçümü & Değer katmayan \\
\hline Serim & Kumaş poşetinin açılması ve masaya yüklenmesi & Değer katmayan \\
\hline Serim & Pastal altı kâğıdının açılması & Değer katmayan \\
\hline Serim & Pastal altı kâğıdına pastalın sabitlenmesi & Değer katmayan \\
\hline Serim & Pastal altı kâğıdının kesilmesi & Değer katmayan \\
\hline Serim & İğne ayarının yapılması & Değer katmayan \\
\hline Serim & Kumaş serme ișlemi & Değer katan \\
\hline Serim & İğnelerin kumaşa geçirilme işlemi & Değer katmayan \\
\hline Serim & Sakat kumaşın kesilmesi & Değer katmayan \\
\hline Serim & Pastal katının sayılması & Değer katmayan \\
\hline Serim & Kumaşın makas ile kesilmesi & Değer katmayan \\
\hline Serim & Milaj kâğıdının açılması & Değer katmayan \\
\hline Serim & Milaj kâğıdının kesilmesi & Değer katmayan \\
\hline Serim & Milaj kâğıdının serilmesi ve iğne ile sabitlenmesi & Değer katmayan \\
\hline Serim & Milaj kâğıdının pastala sabitlenmesi & Değer katmayan \\
\hline Serim & Pastalın cuttera götürülmesi & Değer katmayan \\
\hline Serim & Kumaș serim formunun kesime götürülmesi & Değer katmayan \\
\hline Kesim & Pastalın serim masasından cuttera çekilmesi & Değer katmayan \\
\hline Kesim & Pastal üzerine naylonun serilmesi ve vakumlanması & Değer katmayan \\
\hline Kesim & Pastal bilgilerinin cuttera girilmesi & Değer katmayan \\
\hline Kesim & Cutterın eksen alması & Değer katmayan \\
\hline Kesim & Cutterın parça kesimi & Değer katan \\
\hline Kesim & Demetlerin alınıp arabaya konması & Değer katmayan \\
\hline Kesim & Firelerin kaldırılması & Değer katmayan \\
\hline Meto & İşlerin arabadan alınması ve masaya konması & Değer katmayan \\
\hline Meto & Beden beden ișlerin ayrılması & Değer katmayan \\
\hline Meto & Milaj kâğıdının kaldırılması & Değer katmayan \\
\hline Meto & Regule yapılması & Değer katmayan \\
\hline Meto & Milaj kâğıdının tekrar konması & Değer katmayan \\
\hline
\end{tabular}


G. Çelebi Gürsoy - M. S. Yıldız 13/2 (2021) 1553-1573

\begin{tabular}{lll}
\hline Meto & Meto aletinin ayarlanması & Değer katmayan \\
\hline Meto & Kâğıda her bedende adet yazma & Değer katmayan \\
\hline Meto & Meto vurma işlemi & Değer katan \\
\hline Meto & Demeti katlama & Değer katmayan \\
\hline Tasnif & Arabaya işlerin konması & Arabadan demetlerin alınması ve masaya konması \\
\hline Tasnif & Büyük beden demetlerin açılması & Değer katmayan \\
\hline Tasnif & Milaj kâğıdının kaldırılması & Değer katmayan \\
\hline Tasnif & Tasnifin yapılması & Değer katmayan \\
\hline Tasnif & Milaj kâğıdının konması & Değer katan \\
\hline Tasnif & Büyük beden demetlerin katlanması & Değer katmayan \\
\hline Tasnif & Model ve renk kodunun yazılması & Değer katmayan \\
\hline Tasnif & Fazla adetin katlanması & Değer katmayan \\
\hline Tasnif & Demetlerin arabaya konması & Değer katmayan \\
\hline Tasnif & Sakat işin kesilmesi & Değer katmayan \\
\hline
\end{tabular}

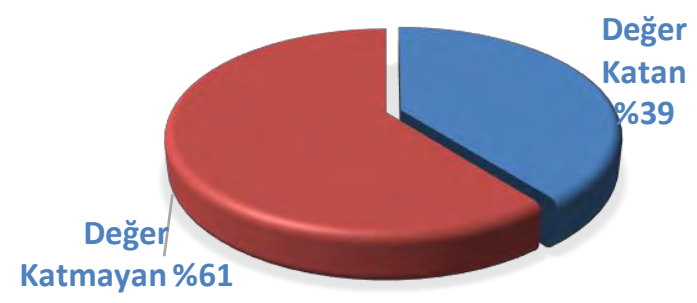

Şekil 5. Kesimhane Değer Yüzdesi

Şekil 5 incelendiğinde kesimhane bölümünün \%61'lik kısmının değer katmayan, \%39'luk kısmının ise değer katan faaliyetlerden meydana geldiği görülmüştür.

Tablo 4. Dikimhane Bölümünde Değer Katan ve Değer Katmayan Aktiviteler

\begin{tabular}{|c|c|c|}
\hline Proses & Operasyon & $\begin{array}{l}\text { Değer katan/Değer } \\
\text { Katmayan }\end{array}$ \\
\hline Hazırlık & İşlerin tasnif bölümünden getirilmesi & Değer katmayan \\
\hline Hazırlık & BOM sayfasının alınması & Değer katmayan \\
\hline Hazırlık & Meto takip çizelgesinin fotokopi çekimi için alınması & Değer katmayan \\
\hline Hazırlık & Fotokopinin çekilmesi & Değer katmayan \\
\hline Hazirlık & Meto takip çizelgesinin geri bırakılması & Değer katmayan \\
\hline Hazırlık & BOM ve meto çizelgesinin sekreterliğe konması & Değer katmayan \\
\hline Hazırlık & İșlerin masaya konması ve beden beden ayrılması & Değer katmayan \\
\hline Hazırlık & $\begin{array}{l}\text { Meto takibinin, eşleme işleminin ve adet karşılaştırma işleminin } \\
\text { yapılması }\end{array}$ & Değer katmayan \\
\hline Hazırlık & İșlerin arabaya konması & Değer katmayan \\
\hline Hazirlık & $\begin{array}{l}\text { A4 alınması ve A4'e modelle ilgili gerekli bilgilerin yazılması ve } \\
\text { rafa yapıştırılması }\end{array}$ & Değer katmayan \\
\hline Baskı & Arabanın hazırlık bölümünden getirilmesi & Değer katmayan \\
\hline Baskı & İșlerin raftan alınması ve baskıya getirilmesi & Değer katmayan \\
\hline Baskı & Ölçülerin kâğıda yazılması & Değer katmayan \\
\hline Baskı & Baskının getirilmesi & Değer katmayan \\
\hline Baskı & Baskının derecesinin 180'den 150'ye düşmesi için beklenmesi & Değer katmayan \\
\hline Baskı & Ön/Arka bask1 operasyonunun yapılması & Değer katan \\
\hline Baskı & İşlere hava tutulması & Değer katmayan \\
\hline Baskı & Beden değişikliği ayarının yapılması & Değer katmayan \\
\hline Baskı & Ön baskıda küçük beden işlerin düzeltilmesi & Değer katmayan \\
\hline Baskı & Arka baskıda kalıp ayarlama & Değer katmayan \\
\hline Baskı & İşlerin arabaya konması & Değer katmayan \\
\hline Cep Hazırlık & Ceplerin otomata hazırlık elemanının getirmesi & Değer katmayan \\
\hline Cep Hazırlık & Cepleri beden beden ayırma ve eșleme işlemi & Değer katmayan \\
\hline Cep Hazırlık & Bobinlerin değiştirilmesi & Değer katmayan \\
\hline Cep Hazırlık & İpin iğneye takılması & Değer katmayan \\
\hline Cep Hazırlık & Cep ağızlarının arka arkaya dikilmesi & Değer katan \\
\hline
\end{tabular}


G. Çelebi Gürsoy - M. S. Yıldız 13/2 (2021) 1553-1573

\begin{tabular}{lll}
\hline Cep Hazırlık & Ceplerin kesilip toplanması & Değer katmayan \\
\hline Cep Otomatı & İşlerin paletten alınması & Değer katmayan \\
\hline Cep Otomatı & Pastal üstü kağıdının atılması & Değer katmayan \\
\hline Cep Otomatı & Otomatta cep dikiminin yapılması & Değer katan \\
\hline Cep Otomatı & Otomatın katladığı işlerin masaya serilmesi & Değer katmayan \\
\hline Cep Otomatı & Her bedende seyyar kalıp koyma ve makinaya meto yapış̧ırma & Değer katmayan \\
\hline Cep Otomatı & Otomatta dikilmeyen işi sökme ve tekrar ayarlama & Değer katmayan \\
\hline Cep Otomatı & Makineye ip takma & Değer katmayan \\
\hline Cep Otomatı & Kalıp değiştirme & Değer katmayan \\
\hline Cep Otomatı & İşleri palete bırakma & Değer katmayan \\
\hline Dikim & Modelin dosyasının bulunması & Değer katmayan \\
\hline Dikim & Baskının aksesuardan alınması & Değer katmayan \\
\hline Dikim & İşlerin banta getirilmesi & Değer katmayan \\
\hline Dikim & Teknikerin beklenmesi & Değer katmayan \\
\hline Dikim & Basınç ayarının ayarlanması & Değer katmayan \\
\hline Dikim & Transfer baskının yapıllması & Değer katan \\
\hline Dikim & Bekleme & Değer katmayan \\
\hline Dikim & Dikim, ütü ve kontrol işlemlerinin yapılması & Değer katan \\
\hline
\end{tabular}

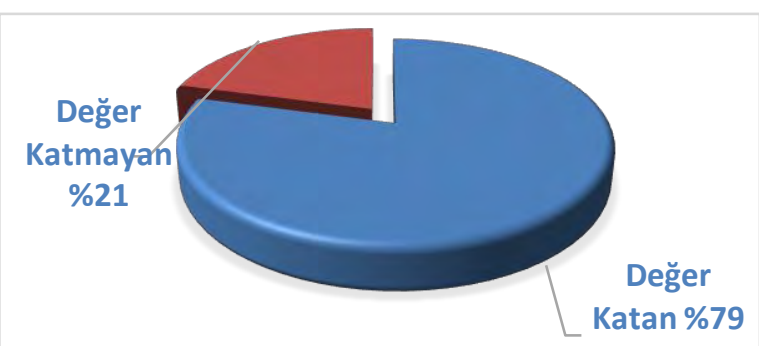

Şekil 6. Dikimhane Değer Yüzdesi

Şekil 6 incelendiğinde dikimhanenin \%21'lik kısmının değer katmayan \%79'luk kısmının ise değer katan aktivitelerden meydana geldiği görülmektedir.

Tablo 5. Paketleme Bölümünde Değer Katan ve Değer Katmayan Aktiviteler

\begin{tabular}{lll}
\hline Proses & Operasyon & $\begin{array}{l}\text { Değer Katan/ Değer } \\
\text { Katmayan }\end{array}$ \\
\hline Paketleme & Kartların aksesuardan alınması & Değer katmayan \\
\hline Paketleme & İşlerin raftan alınması ve masaya konması & Değer katmayan \\
\hline Paketleme & Üst bedenlere kartın takılması & Değer katan \\
\hline Paketleme & Üst beden işlerin rafa konması & Değer katmayan \\
\hline Paketleme & Bekleme & Değer katmayan \\
\hline Paketleme & Üst adetlerinin raftan alınması, masaya konması & Değer Katmayan \\
\hline Paketleme & Üst bedenlerin arasından kâğıdın çıartılıası & Değer katmayan \\
\hline Paketleme & Alt adetlerinin kasadan alınması ve masaya konması & Değer katmayan \\
\hline Paketleme & Alt işlerin açılıp katlanması & Değer Katan \\
\hline Paketleme & Üst işlerin açılıp katlanması ve alt işin arasına konması & Değer Katan \\
\hline Paketleme & İşlerin poşete geçirilmesi & Değer Katan \\
\hline Paketleme & İşlerin kasaya konması & Değer Katmayan \\
\hline Paketleme & $\begin{array}{l}\text { Isşlerin iğne dedektörünün olduğu yere taşınması ve iğne } \\
\text { dedektöründen geçirilmesi }\end{array}$ & Değer Katmayan \\
\hline Paketleme & İşlerin barkodlarının tek tek okutulması ve kasaya konması & Değer Katan \\
\hline Paketleme & Transpaletin depodan getirilmesi & Değer Katmayan \\
\hline Paketleme & İşlerin depoya götürülmesi & Değer Katmayan \\
\hline
\end{tabular}




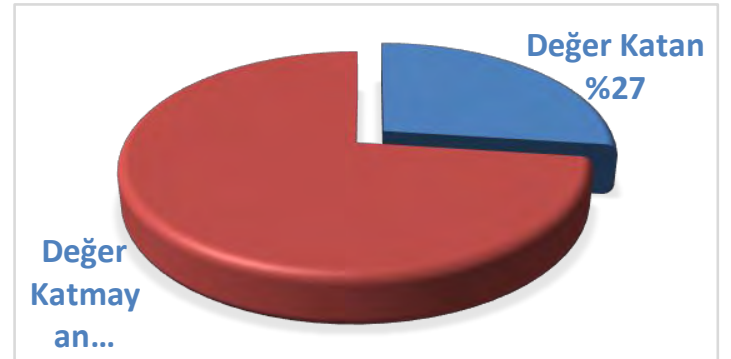

Şekil 7. Paketleme Değer Yüzdesi

Şekil 7 incelendiğinde \%73'lük kısmının değer katmayan, \%27'lik kısmının ise değer katan aktivitelerden meydana geldiği görülmektedir.

\subsubsection{Analiz (Analyze) Aşaması}

Yapılan tanımlama ve ölçme işlemleri gerçekleştirildikten sonra süreç pareto ve neden-sonuç şemasıyla analiz edilmiştir.

\section{- Pareto Şemasi}

80/20 kuralı olarak da bilinen pareto şeması hataların \%80'inin aslında nedenlerin \%20'lik kısmına denk geldiği savunulmaktadır (Ata vd., 2020). Bu aşamada kalite güvence ekibinin tutmuş olduğu raporlardan faydalanılarak bir analiz yapılmıştır. Sürecin pareto analizi Şekil 8'deki gibidir.

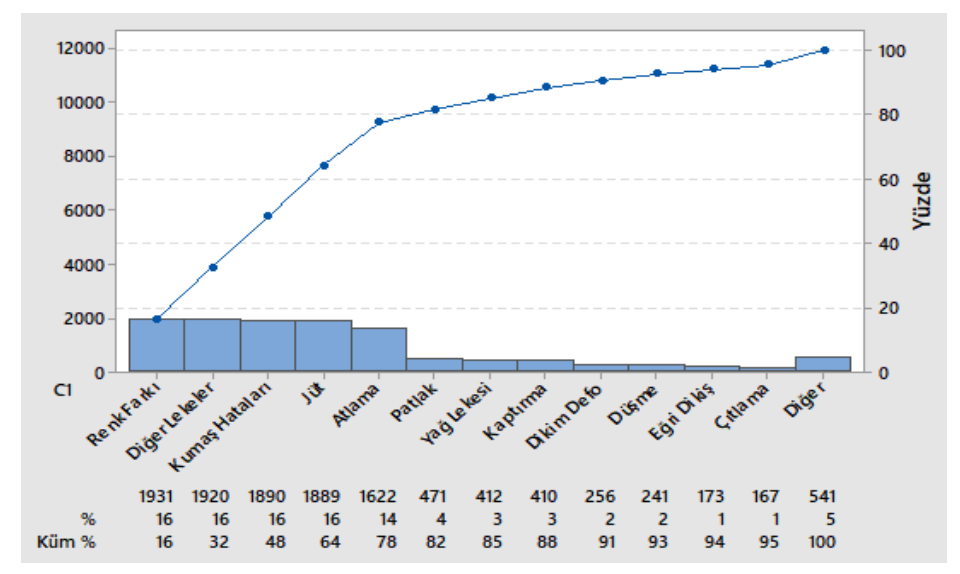

Şekil 8. Pareto Analizi

Şekil 8 incelendiğinde pareto analizi mantığı ile sebebin \%20'lik kısmı hataların \%80'lik kısmını oluşturduğu görülmektedir. Bu noktada \%20'lik kısma denk gelen ilk beş sebebin ortadan kaldırılması işletmede meydana gelen hataların büyük bir kısmının ortadan kaldırılması anlamına gelmektedir. Bu noktada bu hatalar göz önünde bulundurularak yönetim ile toplantılar yapılmış ve hatanın ana sebebini bulmak için neden-sonuç şeması geliştirilmiştir.

\section{- Neden ve Sonuç Şeması}

Ekip üyelerinin amacı, X hazır giyim işletmesinin üretim sürecindeki toplam hataları ve katma değeri olmayan faaliyetleri azaltmaktır. Nitekim neden ve sonuç şemasının amacı, üründe meydana gelen hataların yoğunluğunu gözlemlemek ve meydana geldikleri gerçek hata kaynağını bulmaktır. Bu sayede hatanın kök nedenine inilip ana soruna odaklanılmış olunacaktır. Yapılan araştırmalar ve üst yönetim ile yapılan görüşmeler neticesinde olası nedenler Şekil 9'da gösterilen neden-sonuç şemasında verilmiştir. 


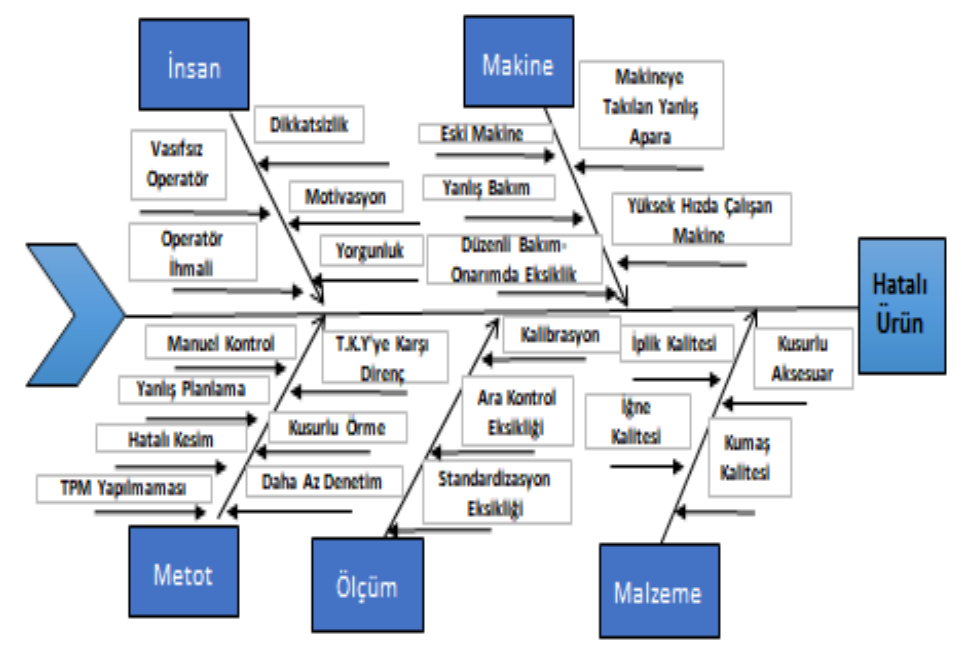

Şekil 9. Neden ve Sonuç Şeması

Şekil 9 incelendiğinde hatalı ürün çıkmasının beş önemli faktörü vardır bunlar; insan makine, metot, ölçüm ve malzemedir. Yapılan beyin fırtınası neticesinde bu beş faktör de kendi içlerinde alt faktörlere ayrılmıştır. Pareto analizinden elde edilen veriler ile de hata oranlarının en yüksek çıktığı hata türlerinin insan, makine ve malzemeden kaynaklandığı tespit edilmiştir. Hatalı ürün çıkmasına sebebiyet veren bu üç önemli faktörün yalın altı sigma uygulamalarıyla iyileştirilmesi hedeflenmektedir. Aynı zamanda işletme de malzemeden kaynaklanan hataların daha çok kumaşın kalitesinden kaynaklanmakta olup kumaş kontrol makinesi ile kontrolü sağlanarak üretim sürecine girmeden hatanın tespitinin sağlanması istenmektedir.

\subsubsection{Faz Geliştirme (Improvement) Aşaması}

Takım yaratıcıllğı ve takım ruhu çoğu zaman maksimum kazanç sağlayacak çözümler üretmeye yardımcı olmaktadır. Bu aşamada toplanan veriler, bir iyileştirme ölçütü olarak temel verilere göre gözden geçirilmektedir. Bunu da gelecek durum haritasında yapılan iyileştirmeler ve neden doğrulama ile gerçekleştirmektedir.

\section{- Gelecek Durum Haritası}

X Hazır Giyim İşletmesinin üretim sürecinin gelecek durum haritası Şekil 10 ve Şekil 11'de gösterilmektedir. Gelecek durum haritasının tanımlanması ve oluşturulma süreci iyileştirme için hedef alanların ortaya çıkmaya başladığı mevcut durum haritasının oluşturulması aşamasında başlamaktadır. İşletmenin mevcut durum haritasına bakıldığı zaman gelecek durum haritası prosesler arası stoklar, bekleme zamanları, üretim akış süresi, işlem süresi, çevrim zamanları ve hazırlık zamanları gibi verilerin iyileştirilmesi sonucunda oluşturulmuştur. Aynı zamanda gelecek durum haritasında çevrim zamanlarında değer katmayan faaliyetleri azaltarak değer katan faaliyetlerin arttırılması sağlanmaktadır. Tüm değer akışının oluşturulması sağlanırken bekleme, stok ve üretim akış süresinin azaltılması sağlanmaktadır. Stok seviyesinin yüksek olması ürünün teslim süresinin uzaması anlamına gelmektedir. Bu yüzden stok seviyesini düşürmek işletmenin maliyetinin düşürülmesini ve kısa teslim zamanı sağlayacaktır. 


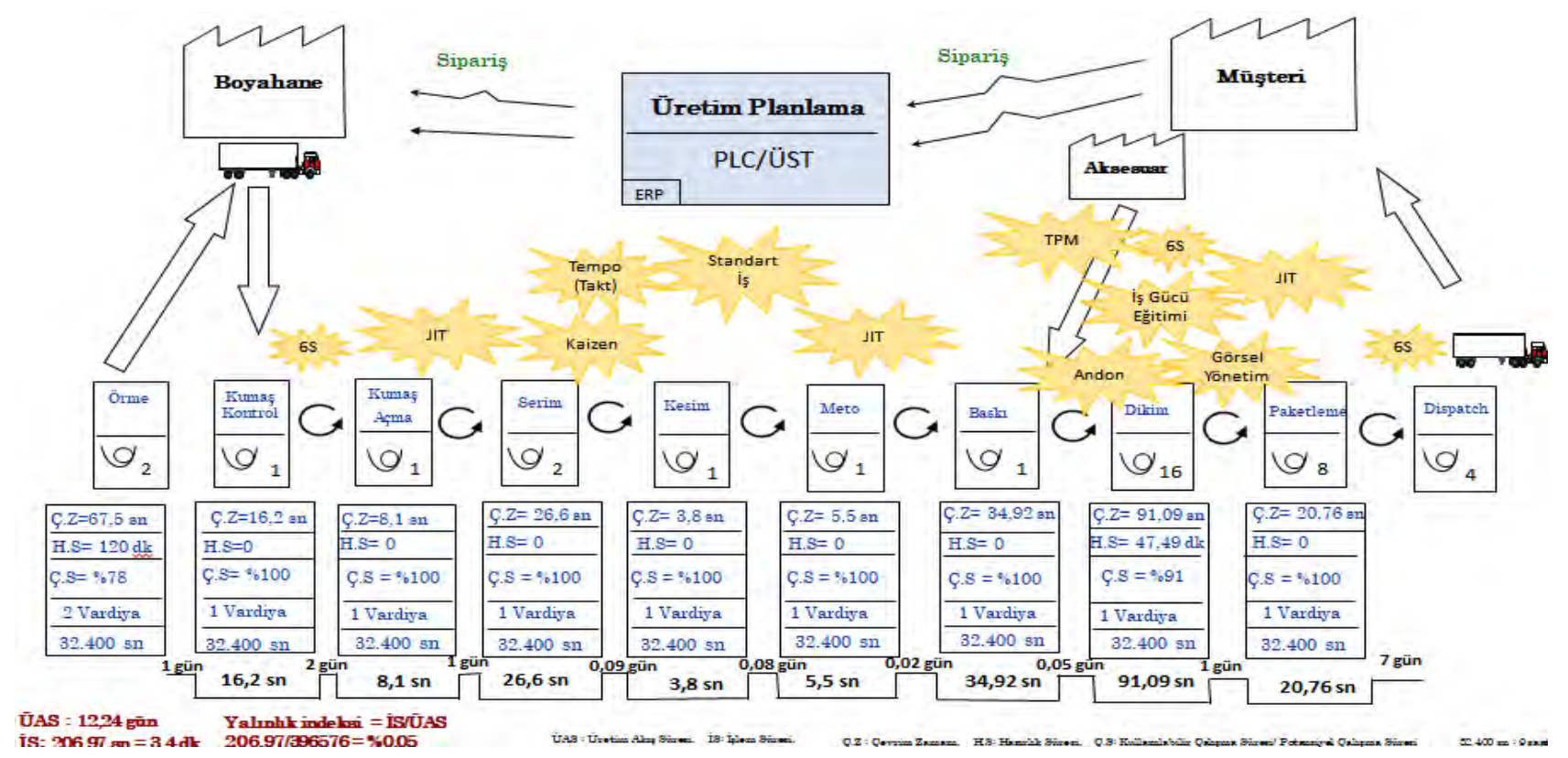

Şekil 10. Takım Üst için Gelecek Durum Haritası

Yapılan tüm yalın altı sigma çalışmaları neticesinde Şekil 10'da verilen takım üst için elde edilen değerler incelendiğinde üretim akış zamanının 49,16 günden 12,24 güne, işlem zamanının 304,82 saniyeden 206,97 saniyeye düştüğü görülmektedir. Yalınlık indeksinin ise \%0,02 den \%0,05 değerine çıktığı hesaplanmıştır.

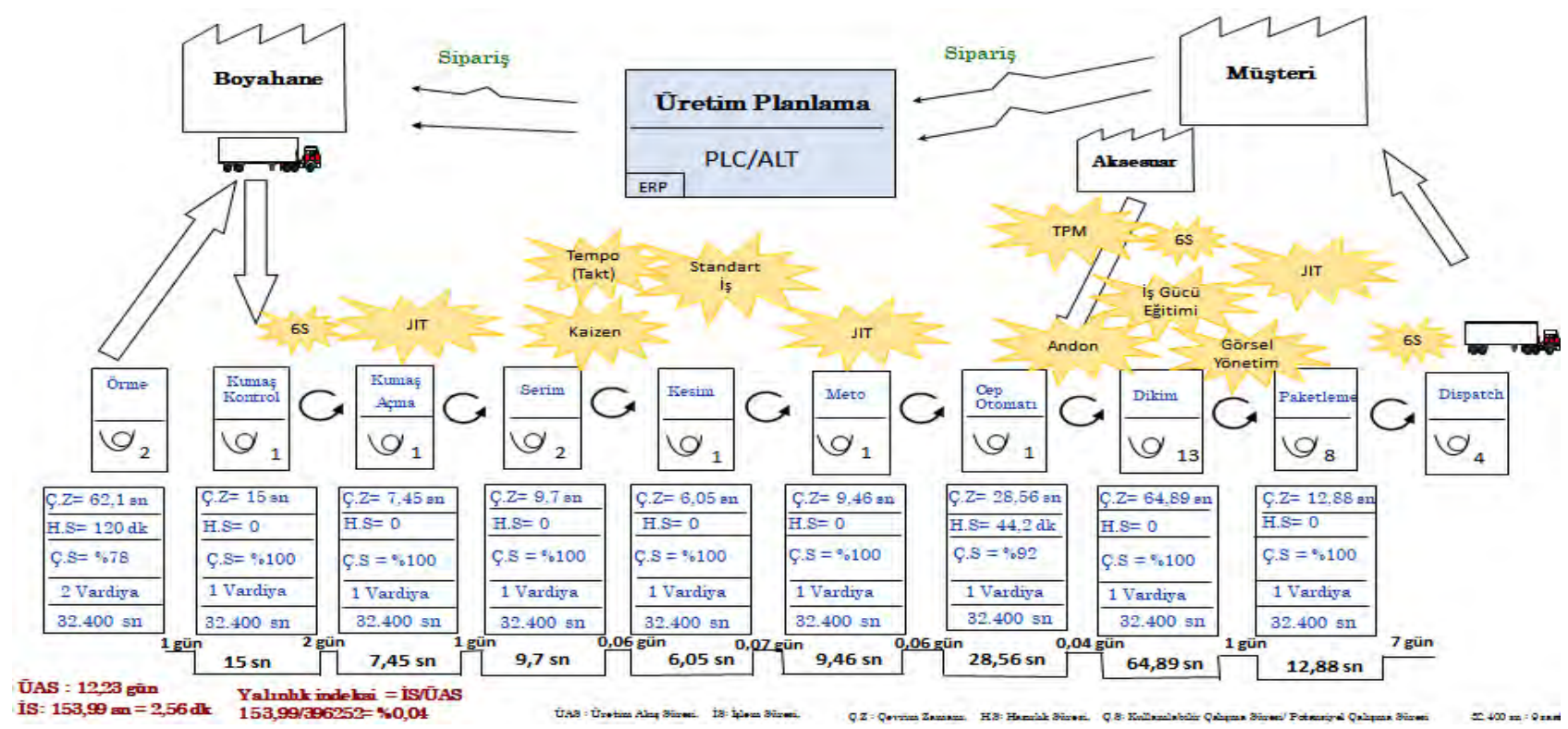

Şekil 11. Takım Alt için Gelecek Durum Haritası

Şekil 11'deki takım alt için elde edilen değerler incelendiğinde ise üretim akış zamanının 49,24 günden 12,23 güne, işlem zamanının 230,64 saniyeden 153,99 saniyeye düştüğü görülmektedir. Yalınlık indeksi ise $\% 0,01$ 'ten \%0,04 değerine çıkmıştır. Burada üretim akış süresinin düşmesinde önemli olan bir diğer faktör ise modellerin sezon başında planlaması yapılırken alt-üst modellerinin bantlardan aynı zaman diliminde çıkabilecek şekilde yapılmasına daha çok dikkat edilmesidir.

\subsubsection{Kontrol Aşaması}

Kontrol adımında, yapılan tüm aşamaların kontrolünün ve sürdürülebilirliğin sağlanması ana amaçtır. İşletmenin mevcut durumunu geliştirmek için ne kadar iyileştirmeler yapılsa da kontrol mekanizması ve sürdürülebilirlik sağlanmazsa yapılan iyileştirmelerin hiçbir etkisi olmayacaktır. Bu yüzden çalışmanın amacı sadece süreç performansını geliştirmek değil, aynı zamanda uzun vadede iyileştirilmiş sonuçları sürdürmektir. 


\section{- Kontrol Grafiği}

Kontrol şeması, imalat işleminin istatistiksel olarak kontrol altında mı yoksa kontrol dışı mı olduğunu belirlemek için geliştirilen istatistiksel bir süreç kontrol aracıdır. Üretim sürecinde ne kadar değişkenlik olduğunu ve hata yoğunluğunu göstermektedir. Kontrol şeması mevcut işlemin kontrol altında olduğunu gösteriyorsa, herhangi bir değişikliğe gerek yoktur. Fakat kontrolden çıkma durumunda, süreçte meydana gelen aksilikler olduğu anlamına gelmektedir bu yüzden belirli işlem parametrelerinin değiştirilmesi gerekir. Bu noktada iyileştirme öncesi 15 günlük verilerden oluşturulan kontrol grafiği Şekil 12' deki gibidir.

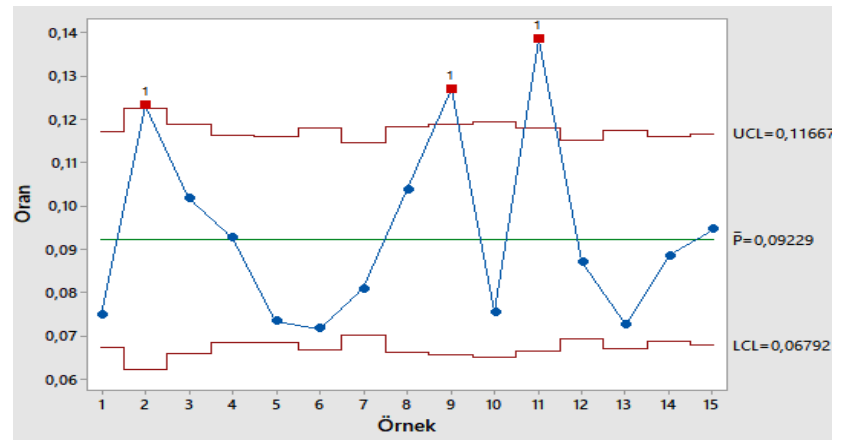

Şekil 12. İyileştirme Öncesi Kontrol Grafiği

Şekil 12 incelendiğinde 2. 9. ve 11. günlerde prosesin üst kontrol noktasından saptığ1 görülmüştür. Bu sapmaların iki sebebi vardır bunlardan biri 2. ve 9. günde ortaya çıkan operatörlerin dikkatsiz tavrı, bir diğeri ise 11. günde meydana gelen makineden kaynaklı ayar bozukluğudur. Operatörlerden kaynaklanan bu sapmaların verimlilik ve kalite yönetim cihazlarıyla ve bazı yalın üretim teknikleriyle iyileştirileceği düşünülmektedir. Makinada meydana gelen ayar bozukluklarıyla ilgili ise mekanik elemanlarıyla durum periyodik olarak görüşülmelidir. Ve neler yapılması gerektiği tartışılmalıdır. Yapılan iyileştirmeler sonrasında tekrar Şekil 13'deki gibi kalite kontrol grafiği oluşturulmuştur.

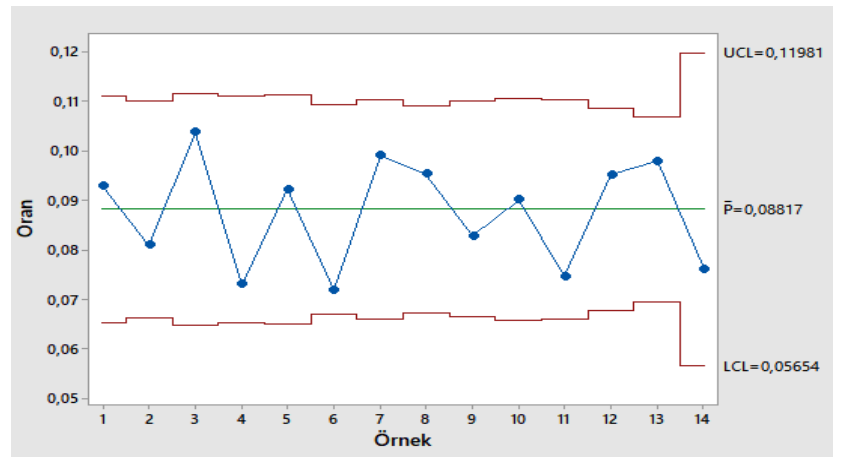

Şekil 13. İyileştirme Sonrası Kontrol Grafiği

Şekil 13'de 14 günlük verilerden oluşturulan kontrol grafiğinde herhangi bir sapma görülmemiştir. Nitekim takılan verimlilik yönetim cihazlarında kalite hatalarını gösteren ledin yanması operatörün kalitesinin takip edileceği andon sistemi oluşturulmuştur. Bu şekilde operatörler daha dikkatli bir tutum içerisinde operasyonlarını yapmalarını sağlamıştır. Bu sistem ile operatör belli kalite değerinin altına düşerse ledler kırmızıya dönerek şefin duruma müdahale etmesi sağlanmaktadır.

\section{- Sürdürülebilirlik Planı}

Hata azaltma ve israfları ortadan kaldırma ilkesine dayanan yalın altı sigma ile üretim sürecinde gerçekleştirilen iyileştirmeler etkili bir şekilde sürdürülebilmesi sağlanmalıdır. Bu çalışma ile sürdürülebilirlik sağlanırsa işletmenin kalite seviyesinin ve verimlilik seviyesinin artacağı düşünülmektedir. Sürdürebilirliğin sağlanması için zaman zaman kontrol çizelgeleri ve mevcut durum haritasılla mevcut durumun istenilen şartnameye uygun olup olmadığı kontrol edilmeli, DPU, FTY ve OEE vb. değerler güncellenerek takip edilmelidir. Yapılan çalışma sonucunda üretim akış zamanı, işlem zamanı, hazırlık zamanı, DPU, FTY ve OEE gibi parametrelerde iyileştirilme sağlanmıştır. Bu parametrelere ait veriler Şekil 14 ve Şekil 19 arasında verildiği gibidir. 
G. Çelebi Gürsoy - M. S. Yıldız 13/2 (2021) 1553-1573

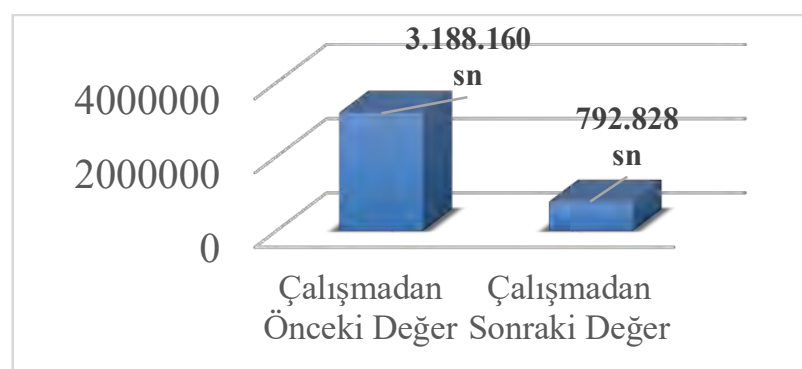

Şekil 14. Üretim Akış Zamanının Azalışı

Şekil 14 incelendiğinde çalışma yapılmadan önce üretim akış zamanının 3.188 .160 saniye olduğu görülmüştür. Yapılan bir takım yalın altı sigma uygulamaları sonrasında bu değer 792.828 saniyeye düşerek iyileşme sağlanmıştır.

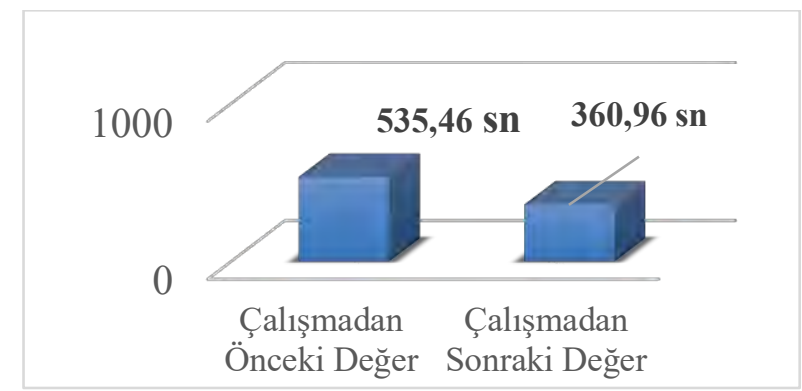

Şekil 15. İşlem Zamanının Azalışı

Şekil 15'de ise yalın altı sigma çalışmasından önceki ve sonraki değerler gösterilmiştir. Çalışmadan önce işlem zamanı 535,46 saniye olan ürünün yalın altı sigma faaliyetleri neticesinde 360,96 saniye olduğu görülmüştür.

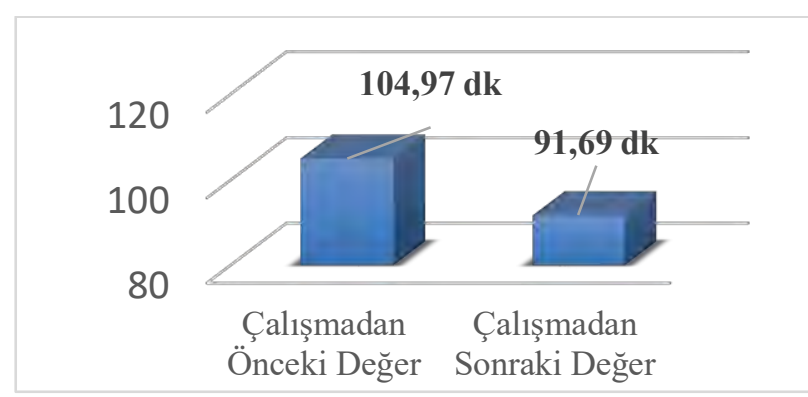

Şekil 16. Hazırlık Zamanının Azalışı

Şekil 16 da değer akış haritalamada ölçülen ürün için hazırlık zamanı süresi verilmiştir. Hazırlık zamanı çalışmadan önce 104,97 dakika olarak saptanmıştır. Yalın altı sigma çalışmasından sonraki değer ise 91,69 dakika olarak hesaplanmıştır.

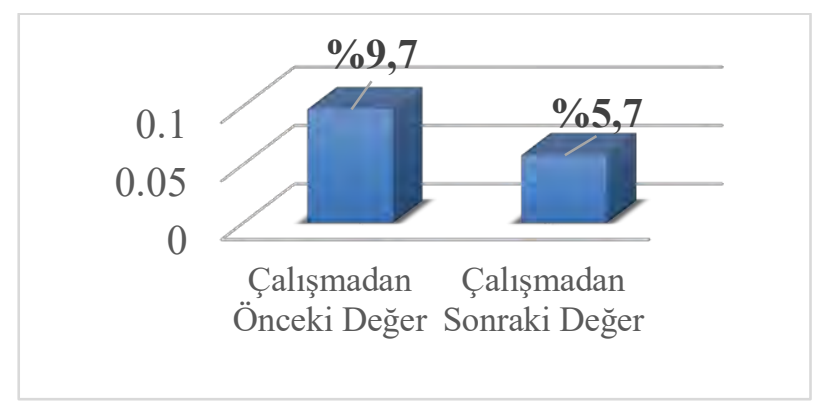

Şekil 17. Birim Başına Hata Oranı (DPU)'nın Azalışı

Şekil 17 incelendiğinde çalışma öncesinde DPU (Defects per Unit) (Birim Başına Hata) değerinin \%9,7 olduğu görülmüştür. Yapılan birtakım iyileştirmeler ve operatörlerin bilinçlendirilmesi ile birim başına hata oranı $\% 5,7^{\prime}$ ye düşmüştür. 
G. Çelebi Gürsoy - M. S. Yıldız 13/2 (2021) 1553-1573

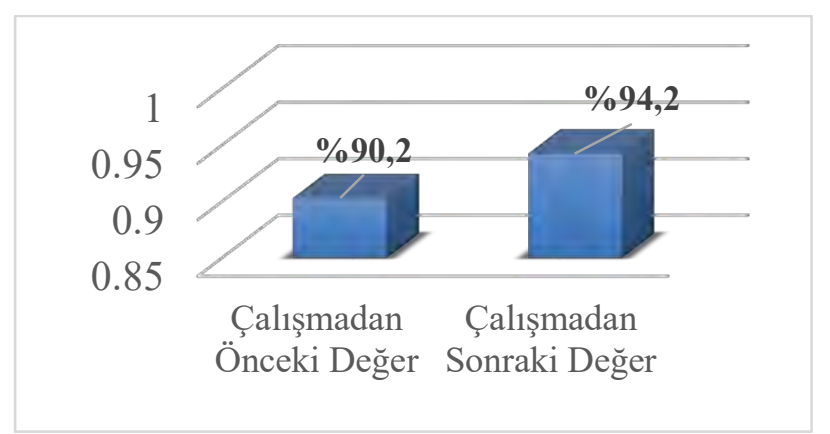

Şekil 18. İlk Zaman Verimi (FTY)'nin Artışı

Şekil 18' de ilk zaman verimi FTY (First Time Yield) (İlk Zaman Verimi) ile ilgili grafik verilmiştir. Yalın altı sigma faaliyetleri öncesinde FTY değerinin \%90,2 olduğu saptanmıştır. Daha sonra bu değer \%94,2 olarak artış göstermiştir.

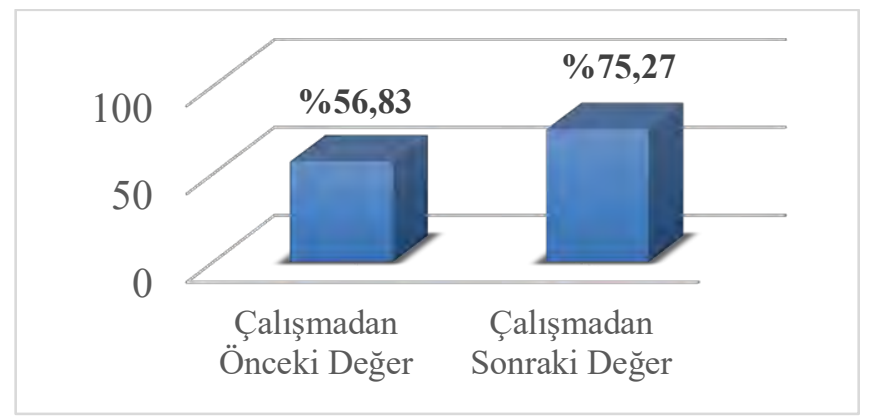

Şekil 19. Genel Ekipman Etkinliği (OEE)'nin Artışı

Şekil 19'da genel ekipman etkinliği OEE (Overall Equipment Effectiveness) (Genel Ekipman Etkinliği) değerinin yalın altı sigma uygulamalarından önce $\% 56,83$ olarak hesaplanmıştır. Bu değer yalın altı sigma uygulamaları neticesinde \%75,27 oranına çıkmıştır. Yalın altı sigma uygulamalarının işletme bünyesine oturtulması ve sürece alışılması neticesinde bu OEE değerinin daha da artacağı düşünülmektedir.

\section{SONUÇ ve TARTIŞMA}

Yalın üretim metodolojisi üretim süreci içerisinde meydana gelen değer katmayan faaliyetlere odaklanarak israfları azaltmaya çalışan bir yöntem iken altı sigma üründe meydana gelen değişime odaklanarak hataları azaltmaya çalışan bir yöntemdir. Bu sebeple yapılan bu çalışma iki yöntemin avantajlarından faydalanarak yalın altı sigma bakış açısıyla incelenmiş ve buna göre süreç iyileştirmesi yapılmıştır. Mükemmelliğe yolculukta yalın altı sigma metodolojisiyle ilgili tekstil sektöründe yapılan çalışmalar yok denecek kadar azdır. Yabancı literatürde de bu durum pek farklı değildir. Bunun sebebi ise yalın üretim ve altı sigmanın bütünleşik gücünün tam anlamıla bilinmemesidir. Bu yüzden bu araştırma ile yalın üretim ve altı sigmanın avantajlarından hareket edilerek yalın altı sigma metodolojisi detaylı olarak incelenmiştir.

Yapılan çalışma ile üretim süreci içerisinde çok fazla sayıda israf ve hatalı ürün olduğu bulgusuna varılmıştır. Bu problemler üründeki İşlem Zamanı'nın ve Hazırlık Zamanı'nın artmasına sebep olduğu gibi prosesler arasındaki stok seviyesinin fazlalı̆̆ı da sürece dahil olunca Üretim Akış Zamanı'nın artmasına neden olmuştur. Sonuç olarak yalın üretim tekniklerinden tam zamanında üretim, kaizen, standart iş, $6 \mathrm{~S}$ ve taktın uygulanması ile Üretim Akış Zamanı, İşlem Zamanı ve Hazırlık Zamanı'nın azalması sağlanmıştır. Bu araştırmaya benzer olarak Vinodh vd., 2011 yılında otomotiv sektöründe yaptıkları bir çalışmada yalın altı sigma araçlarını ve yalın üretim tekniklerinden değer akış haritalandırma, $5 S$ ve toplam üretken bakımı kullanarak üretim akış zamanında \%18,53'lük ve İşlem Zamanı'nda \%25'lik bir azalış sağlamışlardır. Swarnakar vd., 2016 yılında otomotiv sektöründe yaptıkları çalışmada ise yalın altı sigmayı işletmede başarılı bir şekilde uygulamışlar ve yalın üretim tekniklerinden değer akış haritalandırma, SMED ve Poka-Yoke tekniklerini kullanarak Üretim Akış Zamanı'nda \%40,35'lik İşlem Zamanı'nda \%7.10'luk ve Hazırlık Zamanı'nda ise \%14,9'luk bir azalış sağlamışlardır. Yapılan çalışmada bir başka yalın üretim tekniği olan toplam üretken bakımın uygulanması ile çalışanlarda sürece dahil edilmesi ve periyodik bakımın yapılması 


\section{G. Çelebi Gürsoy - M. S. Yıldız 13/2 (2021) 1553-1573}

sayesinde Birim Başına Hata Oranı'nda azalma sağlanmıştır. Aynı zamanda takılan verimlilik yönetim cihazları ile andon tekniğinin uygulanması, kumaş kontrol makinasının sürecin başına konulması, görsel yönetim tekniğinin uygulanması ve işgücü eğitimi ile Birim Başına Hata Oranı'nın azaltılması sağlanmıştır. Bu araştırmaya benzer olarak Kumar vd., 2006 yılında otomotiv aksesuarları üreten bir işletmede yalın üretim tekniklerinden değer akış haritalandırma, $6 \mathrm{~S}$ ve toplam üretken bakım tekniklerini kullanarak yapmış oldukları araştırmada, yalın altı sigma ile Birim Başına Hata Oranı'nda \%96.2'lik bir azalış sağlamışlardır. Vinodh vd., 2011 yılındaki çalışmada ve Swarnakar vd., 2016 yaptıkları çalışmada ise \%50'lik bir azalış sağlamışlardır. Bu noktada Birim Başına Hata Oranı'nın azalması ise İlk Zaman Verimi'nin artmasına sebep olmuştur. Kumar vd., 2006 yılında yaptıkları çalışmada İlk Zaman Verimi'nde \%18,94, Vinodh vd., 2011 yılında yaptıkları çalışmada \%99,5'luk, Swarnakar vd., 2016 yılında yaptıkları çalışmada ise \%0,1'lik bir artış sağlamışlardır. Yapılan bu araştırmada Üretim Akış Zamanı'nın, İşlem Zamanı'nın, Hazırlık Zamanın ve Birim Başına Hata Oranı'nın azalması ise Genel Ekipman Etkinliği'nin artmasına sebep olmuştur. Kumar vd., 2006 yılında yaptıkları çalışmada Genel Ekipman Etkinliği'nde \%72,91, Vinodh vd., 2011 yılında yaptıkları çalışmada \%17,64'lük, Swarnakar vd., 2016 yılında yaptıkları çalışmada ise \%42,18'lik bir artış sağlamışlardır. Ayrıca Swarnakar vd., 2016 yılında yapmış oldukları bu yalın altı sigma çalışmasıyla çalışan sayısını 21 kişiden 19 kişiye günlük üretim sayısını ise 8.000 parçadan 12.000 parçaya çıkartmışlardır.

Araştırma sonucunda tekstil sektöründe faaliyet gösteren işletmelerin yalın altı sigma metodolojisini uygulamaları zor piyasa koşullarında rekabet gücünün artması ve başarılı sonuçlar elde etmesi için kritik öneme sahip olduğu kanısına varılmıştır. Nitekim bu araştırma yalın altı sigmayı uygulamak isteyen işletmeleri hem teorik hem pratik anlamda destekleyebilir. Yine bu araştırma israfları ve hatalı ürünleri minimize etmek isteyen işletmeler için bir rehber olabilir. Aynı zamanda üretim akış zamanı, hazırlık zamanı, işlem zamanı ve birim başına hata oranında azalma sağlanmasını isteyen işletmeler için örnek teşkil edebileceği gibi ilk zaman verimi ve genel ekipman etkinliği değerlerinde de nasıl artmanın sağlanacağına dair fikir verebilir. Araştırılan yöntem ve teknikler sadece tekstil işletmelerinde değil daha farklı birçok işletmede kullanılabilir. Çalışanların katılımını sağlayan bu çalışma ile kişilerin motivasyonunun artması sağlanabilir. Ve üst yönetimden en alt kademeye kadar kişilerin bir bütün olarak hareket etmesini sağlayabilir. Yalın altı sigma yöntemiyle sadece israfların azaltıldığı ve hata oranlarının azaltılarak verimliliğin arttırıldığı bir organizasyon oluşturmak yerine birlikte öğrenen ve kendini geliştiren bir yapı oluşturulabilir.

Yalın altı sigma metodolojisini uygulamak isteyen işletmeler süreç iyileştirmesi kapsamında gerçekleştirmesi gereken bazı öneriler vardır. Bunlar;

- Her şeyden önce yönetimin taahhüdü ve tüm çalışanların katılımı ile yalın altı sigma metodolojisinin benimsenmesi gereklidir.

- İsrafların azaltılması ve hata oranlarının azaltılması için en alt kademeden en üst kademeye kadar herkes birlik beraberlik içinde olmalıdır.

- Hata oranlarının azaltılması için istatistiksel yöntemler kullanılarak süreç takip edilmelidir.

- Hazırlık zamanı, işlem zamanı, üretim akış zamanı ve birim üretim başına kusur (DPU) değerlerinde azalma sağlanması için çalışılmalıdır.

- İlk zaman verimi (FTY) ve genel ekipman etkinliği (OEE) değerlerinde artmanın sağlanması hedeflenmelidir.

- Yalın altı sigmanın başarılı bir şekilde uygulanması sırasında işletme kültürünün değişmesi gerektiğine inanılmalıdir.

- Yalın altı sigma metodolojisi konuda uzman kişilerin desteği ile bir disiplin içerisinde yürütülmelidir.

- Sürecin sürdürülebilirliği için çalışılmalıdır.

Tekstil sektöründe yapılan bu yalın altı sigma çalışması sonrasında ileride yapılacak çalışmalar için bazı öneriler mevcuttur. Bunlar;

- Araştırmacılar yalın altı sigma metodolojisini farklı sektörlerde de uygulayabilirler.

- Araştırmacılar yalın altı sigma metodolojisiyle araştırma yaparken daha farklı yalın üretim tekniklerini araştırmaya dahil edebilirler. 


\section{G. Çelebi Gürsoy - M. S. Yıldız 13/2 (2021) 1553-1573}

- Diğer tekstil işletmelerinde de yalın altı sigma çalışması yapılarak üretim akış zamanı, hazırlık zamanı, işlem zamanı, DPU, FTY ve OEE değerleri arasında karşılaştırmalar yapılabilirler.

- Tekstil endüstrisinde yalın altı sigma etkileri; yalın altı sigmanın çalışanlar arasındaki etkileri ve yalın altı sigma çalışma sonucunda nelerin beklendiğini anlamak için daha geniş bir yelpazeden araştırılabilirler.

- Ayrıca işletme içerisinde yalın altı sigma uygulamalarının sürdürülebilirliği hakkında araştırma yapilabilirler.

\section{KAYNAKÇA}

Ajmera, R. Umarani P. ve Valase K.G., (2017). Lean Six Sigma Implementation in Textile Industry. International Research Journal of Engineering and Technology (IRJET) ISO 9001:2008 Certified Journal, 4(4), 1670-1676.

Akgül, F., (2019). Yalın Altı Sigma: Mobilya Endüstrisinde Bir Araştırma. Hacattepe Üniversitesi Fen Bilimleri Enstitüsü Ağaç İşleri Endüstri Mühendisliği Bölümü, Yüksek Lisans Tezi, Ankara.

Antony, J. (2020). Basic Lean Six Sigma Tools for Higher Education. In Lean Six Sigma in Higher Education. Emerald Publishing Limited.

Assarlind, M., Gremyr, I. ve Bäckman, K. (2013). Multi-Faceted Views On A Lean Six Sigma Application. International Journal of Quality \& Reliability Management, 30(4), 387-402.

Ata, S., Yıldız, M. S. ve Durak, İ. (2020). Statistical Process Control Methods For Determining Defects of Denim Washing Process: A Textile Case From Turkey. Journal of Textile \& Apparel/Tekstil ve Konfeksiyon, 30(3).

Baker M, Jaeger C, Hafley C, et al (2020). Appropriate CT cervical spine utilisation in the emergency Department BMJ Open Quality ;9:e000844. doi: 10.1136/bmjoq-2019-00084.

Chiarini, A., \& Kumar, M. (2020). Lean Six Sigma and Industry 4.0 integration for Operational Excellence: evidence from Italian manufacturing companies. Production Planning $\&$ Control, 1-18.

Çelebi, G. ve Yıldız, M.S. (2020). Bir İmalat İşletmesinde AHP Tabanlı Yalın Üretim Tekniği Seçimi. İşletme Bilimi Dergisi, 8(2), 227-256. DOI: 10.22139/jobs.674846

Drohomeretski, E., Gouvea da Costa, S. E., Pinheiro de Lima, E., ve Garbuio, P. A. D. R. (2014). Lean, Six Sigma and Lean Six Sigma: an analysis based on operations strategy. International Journal of Production Research, 52(3), 804-824.

Eser, S. ve Yıldız M. S. (2018). Tekstil İmalatında Yalın Üretim, Ankara, Nobel Bilimsel Eserler No: 346 (1. Baskı).

Furterer, S. L. (2016). Lean Six Sigma in service: applications and case studies. CRC press..

Gitlow, H., Melnyck, D. ve Levine, M. (2015). A Guide to Six Sigma and Process Improvement for Practitioners and Students: Foundations, DMAIC Tools, Cases, and Certification. (2. Basım). Old Tappan, NJ: Pearson Education,

Gupta, S., Modgil, S. ve Gunasekaran, A. (2020). Big data in lean six sigma: a review and further research directions. International Journal of Production Research, 58(3), 947-969.

Günday, Ü. R., (2019). Yalın Altı Sigma Metodolojisi ve Bankacılık Sektöründe Uygulanması. Sakarya Üniversitesi Fen Bilimleri Enstitüsü Endüstri Mühendisliği Anabilim Dalı. Yüksek Lisans Tezi. Sakarya.

Henrique, D. B., \& Godinho Filho, M. (2020). A systematic literature review of empirical research in Lean and Six Sigma in healthcare. Total Quality Management \& Business Excellence, 31(3-4), 429-449.

Jie, J. C. R., Kamaruddin, S. ve Azid, I. A. (2014). Implementing The Lean Six Sigma Framework İn A Small Medium Enterprise (SME)-A Case Study in A Printing Company. In Proceedings of the 2014 International Conference on Industrial Engineering and Operations Management Bali, 387-395.

Kaswan, M. S., \& Rathi, R. (2020). Green Lean Six Sigma for sustainable development: Integration and framework. Environmental impact assessment review, 83, 106396.

Kozak, N. (2001). Sosyal Bilimlerde Araştırma Yöntemleri, Anadolu Üniversitesi Ders Notları. Eskişehir. 
G. Çelebi Gürsoy - M. S. Yıldız 13/2 (2021) 1553-1573

Kumar, M., Antony, J. Singh R. K, Tiwari M. K. ve Perry D. (2006). Implementing the Lean Sigma framework in an Indian SME: A case study. Production Planning and Control, 17 (4), 407-423.

Kumar, M., Antony, J. ve Tiwari, M.K. (2011). Six Sigma Implementation Framework For Smes-A Roadmap to Manage And Sustain The Change. International Journal of Production Research, 49(18), 5449-5467.

Ma Q., (2014), Lean Six Sigma in Action:Problems and prospects of expansive learning in an international aircraft manufacturer, University of Helsinki, Faculty of Behavioral Sciences, Adult Education and Developmental Work Research, Master's Thesis.

Montgomery, D.C. ve Woodall, W.H. (2008). An Overview Of Six Sigma. International Statistical Review, 76(3), 329-346.

Prasanna, M., \& Vinodh, S. (2013). Lean Six Sigma in SMEs: an exploration through literature review. Journal of Engineering, Design and Technology.

Ricciardi, C., Balato, G., Romano, M., Santalucia, I., Cesarelli, M., \& Improta, G. (2020). Fast track surgery for knee replacement surgery: a lean six sigma approach. The TQM Journal

Sánchez-Rebull, MV, Ferrer-Rullan, R., Hernández-Lara, AB ve Niñerola, A. (2020). Nakit akışı açığını iyileştirmek için Altı Sigma: gıda konservesi imalat endüstrisinde bir vaka çalışması. International Journal of Lean Six Sigma .

Singh, J., Singh, H., Singh, A., \& Singh, J. (2019). Managing industrial operations by lean thinking using value stream mapping and six sigma in manufacturing unit: Case studies. Management Decision.

Sunder M, V., Mahalingam, S., \& Krishna M, S. N. (2020). Improving patients' satisfaction in a mobile hospital using Lean Six Sigma-a design-thinking intervention. Production Planning \& Control, 31(6), 512-526.

Swarnakar, V. ve Vinodh, S., (2015). Deploying Lean Six Sigma framework in an automotive component manufacturing organization. Department of Production Engineering, National Institute of Technology, 267291.

Şahin, O., (2013). İstatistiksel Proses Kontrolünde Proses Yeterlilik Analizi ve Tekstil Endüstrisinde Uygulama. Atatürk Üniversitesi İktisadi ve İdari Bilimler Dergisi, 27(2), 253-271.

Thomas, A., Barton, R. ve Okafor, C.C. (2009). Applying Lean Six Sigma in a Small Engineering Company - A Model For Change. Journal of Manufacturing Technology Management, 20(1), 113-129.

Uluskan, M., \& Oda, E. P. (2020). A thorough Six Sigma DMAIC application for household appliance manufacturing systems. The TQM Journal.

Veena, T.R. ve Prabhushankar, G.V. (2019). A Literature Review On Lean, Six Sigma And ISO 9001:2015 In Manufacturing Industry to Improve Process Performance. Int. J. Business and Systems Research, 13(2), 162-180.

Vinodh, S. Gautham, S.G. ve Ramiya R. A., (2011). Implementing lean sigma framework in an Indian automotive valves manufacturing organisation: a case study. Production Planning \& Control, 22(7), 708722.

Zhang, M., Wang, W., Goh, T.N. ve He, Z. (2014). Comprehensive Six Sigma Application: A Case Study. Production Planning \& Control, 26(3), 1-16. 